\title{
Healthcare resource utilization and costs among nonalcoholic fatty liver disease patients in Germany
}

\author{
Ali Canbay ${ }^{1}$, Nandita Kachru${ }^{\wedge}$, Jennifer Scarlet Haas ${ }^{3}$, Dominic Meise ${ }^{3}$, A. Burak Ozbay ${ }^{2}$, \\ Jan-Peter Sowa ${ }^{1 \wedge}$ \\ ${ }^{1}$ Department of Internal Medicine, Ruhr-University Bochum, Bochum, Germany; ${ }^{2}$ Gilead Sciences, Inc., Health Economics Outcomes Research, \\ Foster City, CA, USA; ${ }^{3}$ Xcenda GmbH, Hannover, Germany \\ Contributions: (I) Conception and design: All authors; (II) Administrative support: All authors; (III) Provision of study materials or patients: All \\ authors; (IV) Collection and assembly of data: All authors; (V) Data analysis and interpretation: All authors; (VI) Manuscript writing: All authors; (VII) \\ Final approval of manuscript: All authors. \\ Correspondence to: Prof. Dr. Ali Canbay. Director of the Department of Internal Medicine, University Hospital Knappschaftskrankenhaus Bochum, \\ Ruhr-University Bochum, In der Schornau 23-25, 44892 Bochum, Germany. Email: Ali.Canbay@ruhr-uni-bochum.de; Dr. Nandita Kachru. Health \\ Economics Outcomes Research, Gilead Sciences Inc., 333 Lakeside Drive, Foster City, CA 94404, USA. Email: Nandita.Kachru@gilead.com.
}

Background: Patients with nonalcoholic fatty liver disease (NAFLD) and nonalcoholic steatohepatitis (NASH) are associated with progression to advanced liver diseases that include compensated cirrhosis, decompensated cirrhosis, liver transplantation, and hepatocellular carcinoma (HCC). This study characterized comorbidities, healthcare resource utilization (HRU), and associated costs among NAFLD patients in Germany.

Methods: German healthcare claims data between 2011 and 2016 were analyzed retrospectively. Adult patients diagnosed with NAFLD and/or NASH were categorized as NAFLD, NAFLD non-progressors, compensated cirrhosis, decompensated cirrhosis, liver transplant, or HCC. Within each stage, annual allcause HRU and costs were measured during the pre- and post-index periods.

Results: Among 4,580,434 patients in the database, proportion of NAFLD was 4.7\% ( $\mathrm{n}=215,655)$. Of them, $36.8 \%$ were non-progressors, $0.2 \%$ compensated cirrhosis, $9.6 \%$ decompensated cirrhosis, $0.0005 \%$ liver transplant, and $0.2 \%$ HCC. Comorbidity rates were significantly higher in compensated cirrhosis, decompensated cirrhosis, and HCC compared with non-progressors (52.07\%, 56.46\%, 57.58\% vs. $27.49 \%$ for cardiovascular disease; $77.13 \%, 76.61 \%, 83.47 \%$ vs. $54.89 \%$ for hypertension; $47.20 \%, 53.81 \%$, $52.89 \%$ vs. $35.21 \%$ for hyperlipidemia; $49.88 \%$, 36.67\%, $48.21 \%$ vs. $20.38 \%$ for type 2 diabetes mellitus). The mean annual numbers of post-index outpatient visits and inpatient hospitalizations were significantly higher in patients with advanced liver diseases versus non-progressors. Mean annual costs were significantly higher among patients with advanced liver diseases (compensated cirrhosis, €10,291; decompensated cirrhosis, €22,561; liver transplant, €34,089; HCC, €35,910) than non-progressors $(€ 3,818, \mathrm{P}<0.001$, except liver transplant cohort). This trend remained consistent after adjusting for baseline demographics and comorbidities.

Conclusions: NAFLD patients in Germany are grossly underdiagnosed and exert substantial healthcare resource use and economic burden, particularly those with advanced liver diseases. Optimal strategies for early identification and management are needed to prevent disease progression and limit the rising costs.

Keywords: Disease burden; advanced liver diseases; Germany; nonalcoholic steatohepatitis (NASH); nonalcoholic fatty liver disease (NAFLD)

^ ORCID: Ali Canbay, 0000-0001-6069-7899; Nandita Kachru, 0000-0002-2754-0723; Jan-Peter Sowa, 0000-0003-2943-0015. 
Submitted Oct 29, 2020. Accepted for publication Feb 10, 2021.

doi: 10.21037/atm-20-7179

View this article at: http://dx.doi.org/10.21037/atm-20-7179

\section{Introduction}

Chronic liver diseases are a worldwide epidemic with potentially dramatic consequences for both quality of life and the economy. Nonalcoholic fatty liver disease (NAFLD) is the leading cause of chronic liver diseases worldwide, mirroring the increasing prevalence of obesity. The estimated global prevalence of NAFLD is currently $24 \%(1,2)$; in Europe, it is estimated to be $20-30 \%$ (3) and in Germany 30\% when diagnosed by ultrasonography (4). Nonalcoholic steatohepatitis (NASH), the progressive phenotype of NAFLD characterized by ballooning of hepatocytes and liver inflammation, can potentially progress in severity to advanced liver diseases, including compensated cirrhosis, decompensated cirrhosis, and hepatocellular carcinoma (HCC), and liver transplantation (5). Patients with NAFLD-associated fibrosis may also have increased risk of morbidity and mortality $(5,6)$, along with impaired health-related quality of life (7). Approximately $5-20 \%$ of NAFLD patients develop NASH globally (8).

Despite its high prevalence and clinical burden, there are no targeted pharmacotherapies for the treatment of NAFLD. The current management strategies include non-pharmacologic (diet, exercise, weight loss) and pharmacologic interventions (pioglitazone, statins, vitamin E supplementation) $(9,10)$.

In itself, the economic burdens of NAFLD and NASH are estimated to be enormous. A previous modeling study for NAFLD estimated the annual direct costs to be $€ 354$ per patient in Germany, totaling up to $\$ 4.3$ billion direct medical costs per year (11). Other studies have reported cost data for patients with NASH. However, these studies used cost estimates for managing other liver diseases as a proxy for disease management costs in NASH patients (12-14). Despite the mounting evidence regarding the clinical and economic implications, there are no robust real-world claims studies in Germany that have comprehensively evaluated the comorbidities, healthcare resource utilization (HRU) and costs among patients with NAFLD or have assessed the economic burden of NAFLD-associated comorbidities. Thus, the aims of this study were to (I) identify and characterize patients with NAFLD, and (II) evaluate their comorbidity burden, HRU, and associated costs, using real-world German healthcare claims data.

The findings from this study can be used to understand the unmet needs of NAFLD patients, thereby allowing more informed decision-making on healthcare resource allocation. Understanding the full disease burden will also help the providers, payers, and policy makers develop future NAFLD identification algorithms, including the high-risk NASH patients, and implement a multifaceted health policy to manage this significant chronic liver disease. We present the following article/case in accordance with the STROBE reporting checklist (available at http://dx.doi.org/10.21037/ atm-20-7179).

\section{Methods}

\section{Study design and data source}

A retrospective longitudinal cohort study was conducted using anonymized claims data from the German Institut für angewandte Gesundheitsforschung (InGef) research database from January 1, 2011 through December 31, 2016 (15-17). The InGef database contains longitudinal information about the demographic characteristics, HRU, mortality, and prescription rates for approximately eight million insured persons residing in Germany, and has good external validity with the German population for morbidity, mortality, and use of prescription drugs (15). An age- and sex-adjusted sample of the InGef database that included approximately four million covered lives, representing $4.8 \%$ of the German population, was used in this study $(15,17)$. The data were obtained from 60 of 109 statutory health insurances in Germany (18). All patient-level data in the InGef database are de-identified to comply with German data protection regulations and German Federal Law, and therefore the study did not require approval from an institutional review board or ethics committee. The study conformed to the Declaration of Helsinki (as revised in 2013), since no research on humans was performed.

\section{Study sample selection}

Patients aged $\geq 18$ years with $\geq 1$ inpatient or verified 
outpatient claim for diagnosis of NAFLD and/or NASH between January 1, 2011 and December 31, 2016 were included. The study relied only on International Classification of Diseases, Tenth Edition, German Modification (ICD-10-GM) codes for identification of NAFLD and/or NASH (due to the unavailability of laboratory/biopsy data in claims database), using K76.0 [fatty (change of) liver, not elsewhere classified applicable to NAFLD] and K75.8 [other specified liver diseases (including NASH and other specified inflammatory liver diseases)]. NASH is accurately diagnosed only through liver biopsy, which in clinical practice is extremely limited by its invasiveness, high cost, and potential for sampling errors (19), resulting in a high likelihood of NASH being severly underdiagnosed in real-world healthcare claims data. Since NASH is a progressive subtype of NAFLD, this study was performed with NAFLD and/or NASH patients combined into a single cohort of NAFLD. Patients with any evidence of other liver etiologies [including viral hepatitis (hepatitis A, B, C, D, E), toxic liver disease, autoimmune hepatitis, Wilson's disease, Gaucher disease, lysosomal acid lipase deficiency, alcoholism including alcoholic liver disease, primary biliary/sclerosing cholangitis, or hemochromatosis] and human immunodeficiency virus infection at any time during the study period were excluded.

Advanced liver diseases were defined as compensated cirrhosis, decompensated cirrhosis, liver transplant and HCC or a sequential development of any of these conditions. The first diagnosis of NAFLD marked the NAFLD index quarter. Following from the NAFLD index quarter, patients were grouped into six groups of liver severity stages as shown in Supplementary Material (Figure S1)—(I) NAFLD; (II) NAFLD non-progressors; (III) NAFLD progressing to compensated cirrhosis; (IV) NAFLD progressing to decompensated cirrhosis; (V) NAFLD progressing to liver transplant; and (VI) NAFLD progressing to HCC. Patients progressing to multiple liver severity stages were included in $>1$ group; thus, the patient groups were not mutually exclusive. Because HRU/cost estimates were allocated by liver severity stages, any kind of over-estimation or double-calculation of HRU/costs for patients in $>1$ group was prevented owing to the patient being censored at disease progression. The pre-index period was defined as the baseline duration of four quarters (1 year) prior to the index quarter, whereas post-index follow-up was defined as starting from their index quarter of diagnosis to the earliest of end of follow-up (1 year), disease progression, death, or the end of the study period (December 31, 2016), when the patient was censored.

\section{Study outcomes}

Baseline demographics and comorbidities were assessed during the pre-index period. Annual all-cause HRU and annual all-cause healthcare cost data were measured in the 1 -year pre-index and post-index periods across all liver severity stages. Annual estimates were obtained from perpatient per-quarter values during the pre-index and postindex periods. All-cause HRU data covered outpatient visits, inpatient hospitalizations, and emergency department visits. All-cause healthcare cost data included costs of inpatient care, outpatient care, outpatient pharmacotherapy, devices and aids, and total costs.

\section{Statistical analysis}

Descriptive statistics were calculated for all variables, including frequency and percent responses for categorical variables, and mean, median, and standard deviation for continuous variables. The Student's $t$-test and the asymptotic Pearson chi-squared test were used for the comparison of continuous and categorical variables, respectively. A two-tailed $\mathrm{P}<0.05$ was considered, a priori, to be statistically significant.

Multivariable analysis was performed using generalized estimating equation (GEE) models with log-link function and gamma distribution to evaluate the post-index total annual healthcare costs (primary dependent variable) associated with liver severity stages including NAFLD non-progressors, compensated cirrhosis, decompensated cirrhosis, liver transplant, HCC (primary independent variable), adjusted for covariates including patients' baseline demographics (age, sex, region) and baseline comorbidities (abdominal pain, anemia, apnea, bariatric surgery, cardiovascular diseases, dyspepsia, hyperlipidemia, hypertension, insomnia, obesity, renal disease, smoking, type 2 diabetes mellitus, thyroid disease, vitamin $\mathrm{D}$ deficiency). GEE models can accommodate auto-correlated and non-normal data, thereby enabling analysis of longitudinal data (participants are repeatedly measured at different timepoints), or clustered data (measurements are taken for participants sharing a common characteristic). All statistical analyses were performed using SAS version 9.4 (SAS Institute, Cary, NC, USA). 


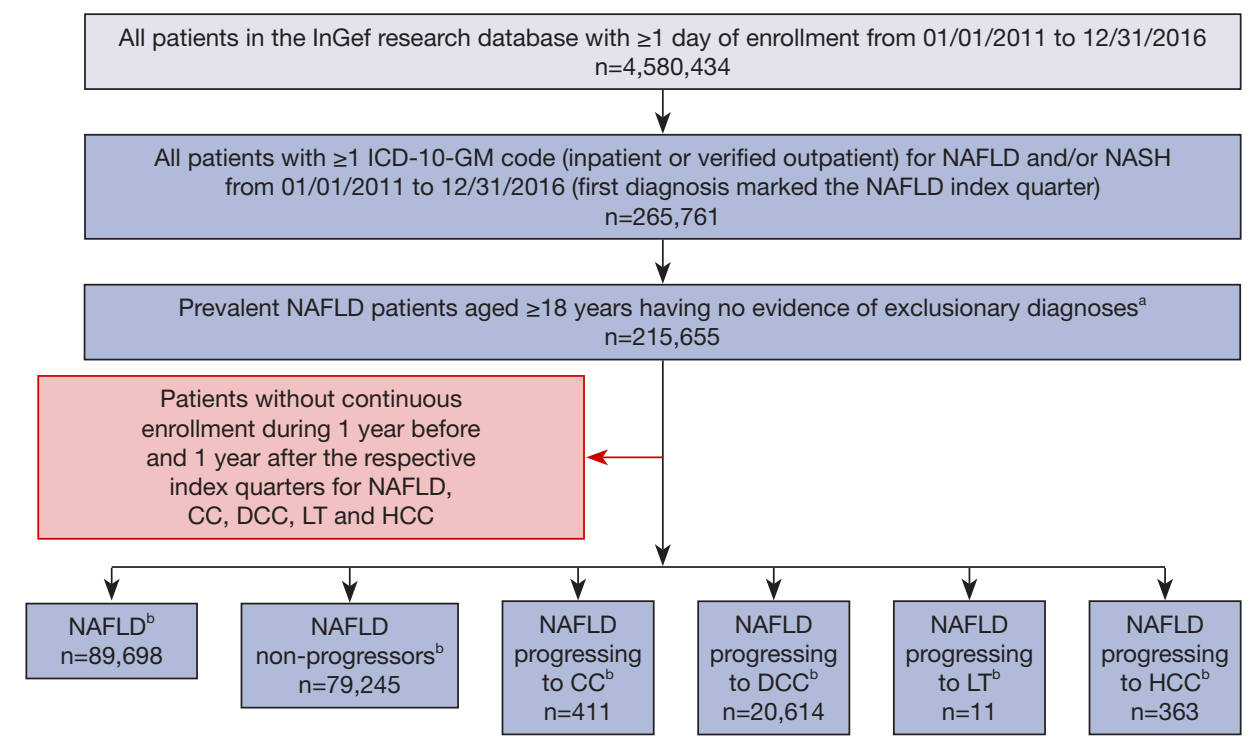

Figure 1 Patient attrition. ${ }^{a}$ Exclusionary diagnoses include other liver etiologies [viral hepatitis (hepatitis A, B, C, D, E), toxic liver disease, autoimmune hepatitis, Wilson's disease, Gaucher disease, lysosomal acid lipase deficiency, alcoholism including alcoholic liver disease,

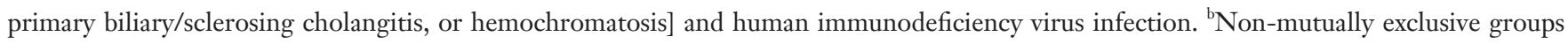
of liver severity stages (since patients progressing to multiple liver severity stages were included in $>1$ group). CC, compensated cirrhosis; DCC, decompensated cirrhosis; HCC, hepatocellular carcinoma; ICD-10-GM, International Classification of Diseases, Tenth Edition, German Modification; InGef, Institut für angewandte Gesundheitsforschung; LT, liver transplant; NAFLD, nonalcoholic fatty liver disease; $\mathrm{NASH}$, nonalcoholic steatohepatitis.

\section{Results}

\section{Study sample selection}

Of the 4,580,434 individuals with $\geq 1$ day of enrollment in the InGef database from 1 January 2011 through 31 December 2016, the study identified 215,655 patients with prevalent NAFLD (4.71\% of the total sample; Figure 1$)$. The proportion of patients with ICD code K75.8 (definite NASH diagnosis) was 1.9\% (4,022 patients). After applying the predefined inclusion/exclusion criteria, an analytical cohort of 89,698 NAFLD patients was identified with no evidence of NAFLD or advanced liver diseases in the year preceding the NAFLD index quarter; further analysis was performed on these incident NAFLD cases. This was done in order to avoid the prevalence bias, that could result in overestimation of HRU or cost estimates due to selfselection of sicker patients who may have had the disease for a longer duration. Subsequent follow-up resulted in identification of 79,245 NAFLD non-progressors (36.75\% of prevalent NAFLD) who had no evidence of progression from NAFLD to compensated cirrhosis, decompensated cirrhosis, liver transplant, or HCC, while 411 patients with compensated cirrhosis (0.19\% of prevalent NAFLD), 20,614 with decompensated cirrhosis $(9.56 \%$ of prevalent NAFLD), 11 with liver transplant $(0.005 \%$ of prevalent NAFLD), and 363 with HCC ( $0.17 \%$ of prevalent NAFLD) patients (Figure 1). A detailed patient attrition flowchart that explains the various exclusion criteria at each stage is shown in Supplementary Material (Figure S2).

\section{Baseline demographics and comorbidities}

The demographics and comorbidities of the liver severity stages are summarized in Table 1 . The mean age of NAFLD patients at index diagnosis was 58.03 years and ranged from 48.82 years (liver transplant) to 71.26 years (HCC) across all stages of liver severity; the majority of patients were male $[54.20 \%$ (decompensated cirrhosis) to $72.73 \%$ (liver transplant)]. In general, patients had a high comorbidity burden, with high rates of comorbid conditions reported for patients with NAFLD (29.41\% cardiovascular diseases, $21.35 \%$ type 2 diabetes mellitus, $35.96 \%$ hyperlipidemia, $56.31 \%$ hypertension, $12.50 \%$ renal disease; Table 1). Of patients with advanced liver diseases, $88.92-94.21 \%$ were 
Table 1 Baseline demographics and comorbidities

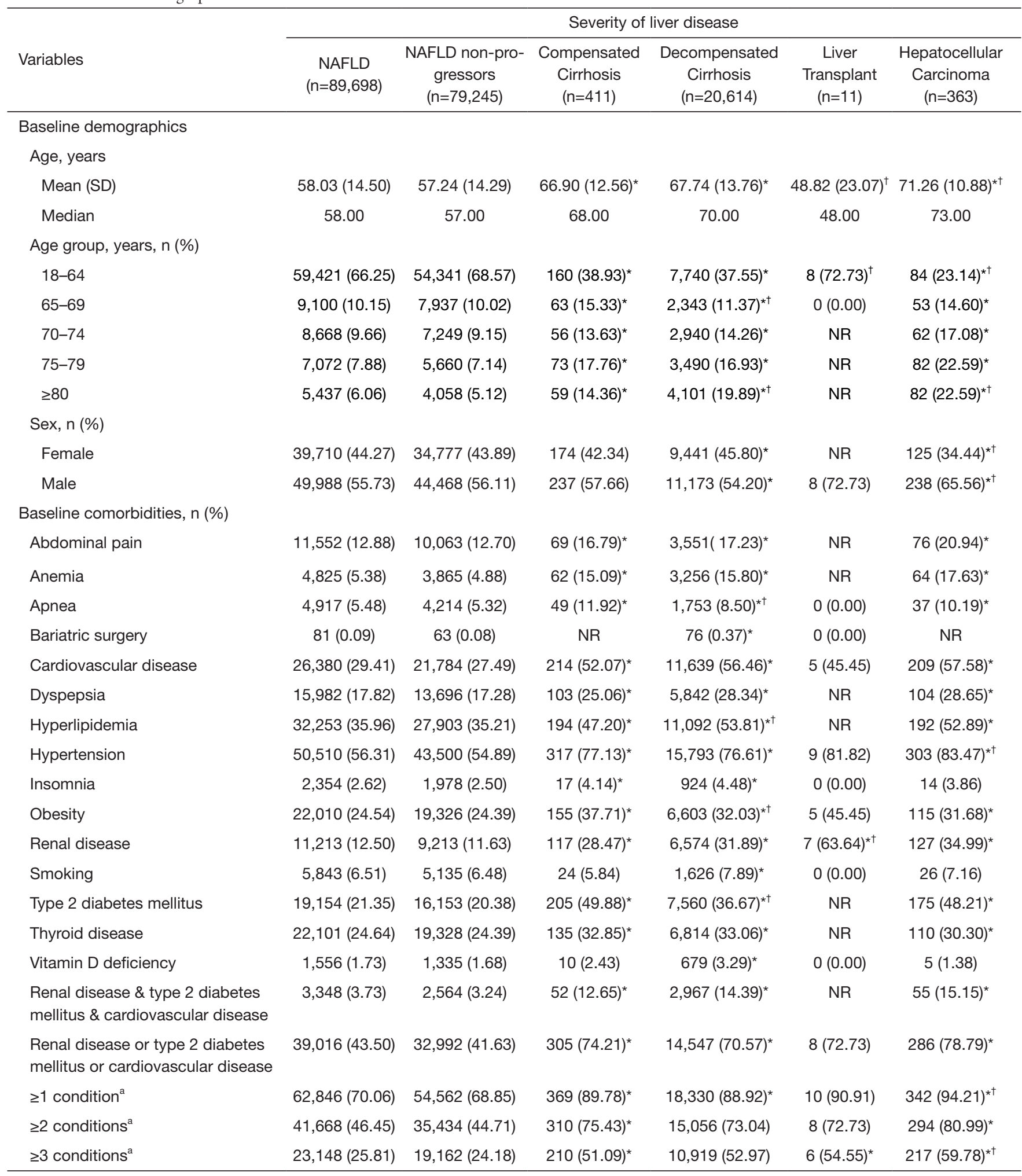

${ }^{a}$ Out of cardiovascular disease, hypertension, hyperlipidemia, renal disease, type 2 diabetes mellitus. ${ }^{*} \mathrm{P}<0.05$ for comparison with NAFLD non-progressors. ${ }^{\dagger} \mathrm{P}<0.05$ for comparison with compensated cirrhosis. NAFLD, nonalcoholic fatty liver disease; NR, not reported (owing to small sample size); SD, standard deviation. 


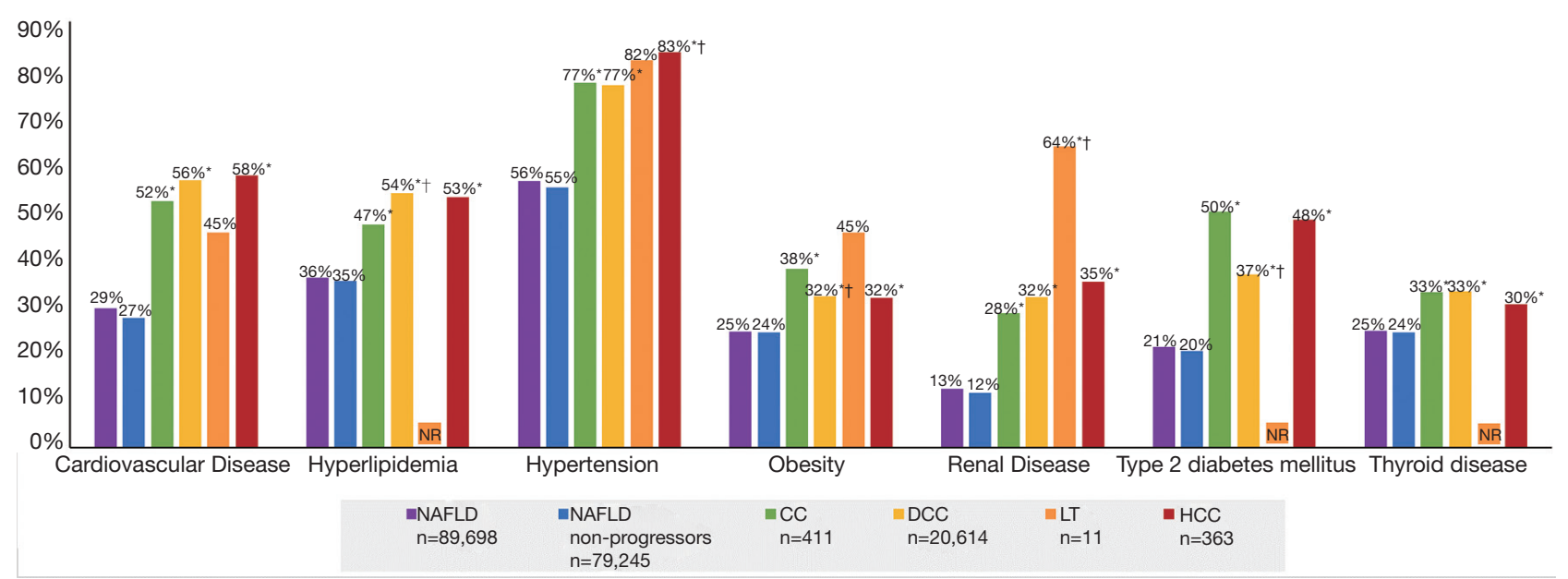

Figure 2 Selected baseline comorbidities. ${ }^{*} \mathrm{P}<0.05$ for comparison with NAFLD non-progressors. ${ }^{\dagger} \mathrm{P}<0.05$ for comparison with compensated cirrhosis. CC, compensated cirrhosis; DCC, decompensated cirrhosis; HCC, hepatocellular carcinoma; LT, liver transplant; NAFLD, nonalcoholic fatty liver disease; NR, not reported (owing to small sample size).

identified with $\geq 1$ of these conditions. Compared with nonprogressors $(3.24 \%)$, patients diagnosed with compensated cirrhosis $(12.65 \%)$, decompensated cirrhosis $(14.39 \%)$, or HCC $(15.15 \%)$ were significantly more likely $(\mathrm{P}<0.0001)$ to have all three comorbidities: renal disease, type 2 diabetes mellitus, and cardiovascular diseases.

Generally, there was a trend of increasing comorbidity burden among patients with NAFLD and advanced liver diseases compared with non-progressors (Table 1, Figure 2). Patients with compensated cirrhosis, decompensated cirrhosis, or HCC had significantly higher rates of comorbidities compared with non-progressors $(\mathrm{P}<0.05)$, and patients with decompensated cirrhosis generally had significantly higher rates of certain comorbidities (such as type 2 diabetes mellitus, obesity, and hyperlipidemia) compared with those with compensated cirrhosis $(\mathrm{P}<0.05)$.

\section{Annual all-cause HRU}

In general, the mean HRU increased in most of the healthcare service categories from the pre-index period to the post-index period (Table 2).

The calculated mean annual numbers of post-index outpatient visits for patients with $\geq 1$ visit were significantly higher in patients with advanced liver disease (compensated cirrhosis, 31.11; decompensated cirrhosis, 32.01; liver transplant, 36.00; HCC, 40.26) when compared with the non-progressors (21.77) $(\mathrm{P}<0.05$; Table 2).
A similar trend was observed among patients in the inpatient setting; $28.46 \%$ of the non-progressors were hospitalized after the index date, compared with 58.64\% of patients with compensated cirrhosis $(\mathrm{P}<0.0001)$ and up to $84.85 \%$ of those with $\mathrm{HCC}(\mathrm{P}<0.0001)$. Mean annual number of admissions, among those patients with $\geq 1$ inpatient hospitalization, were significantly higher for patients with advanced liver diseases (compensated cirrhosis, 2.51; decompensated cirrhosis, 3.49; liver transplant, 2.38; HCC, 4.95) than for non-progressors $(1.75)(\mathrm{P}<0.001$, except for the liver transplant cohort, owing to the small sample size; Table 2).

Among patients with $\geq 1$ inpatient hospitalization, the mean length of stay per patient in the post-index period was also significantly higher for patients with advanced liver diseases (compensated cirrhosis, 23.97 days; decompensated cirrhosis, 44.51 days; liver transplant, 23.63 days; HCC, 53.38 days) than in non-progressors (13.72 days) $(\mathrm{P}<0.0001$, except for liver transplant).

In accordance with the trend observed for outpatient and inpatient visits, the proportion of patients with emergency department visits in the post-index period was significantly higher among patients with advanced liver diseases (compensated cirrhosis, 29.68\%; decompensated cirrhosis, $45.07 \%$; liver transplant, $45.45 \%$; HCC, $52.07 \%)$ than among non-progressors $(14.79 \%, \mathrm{P}<0.05)$.

All-cause HRU stratified by type 2 diabetes mellitus, cardiovascular diseases, and renal disease, are presented in 


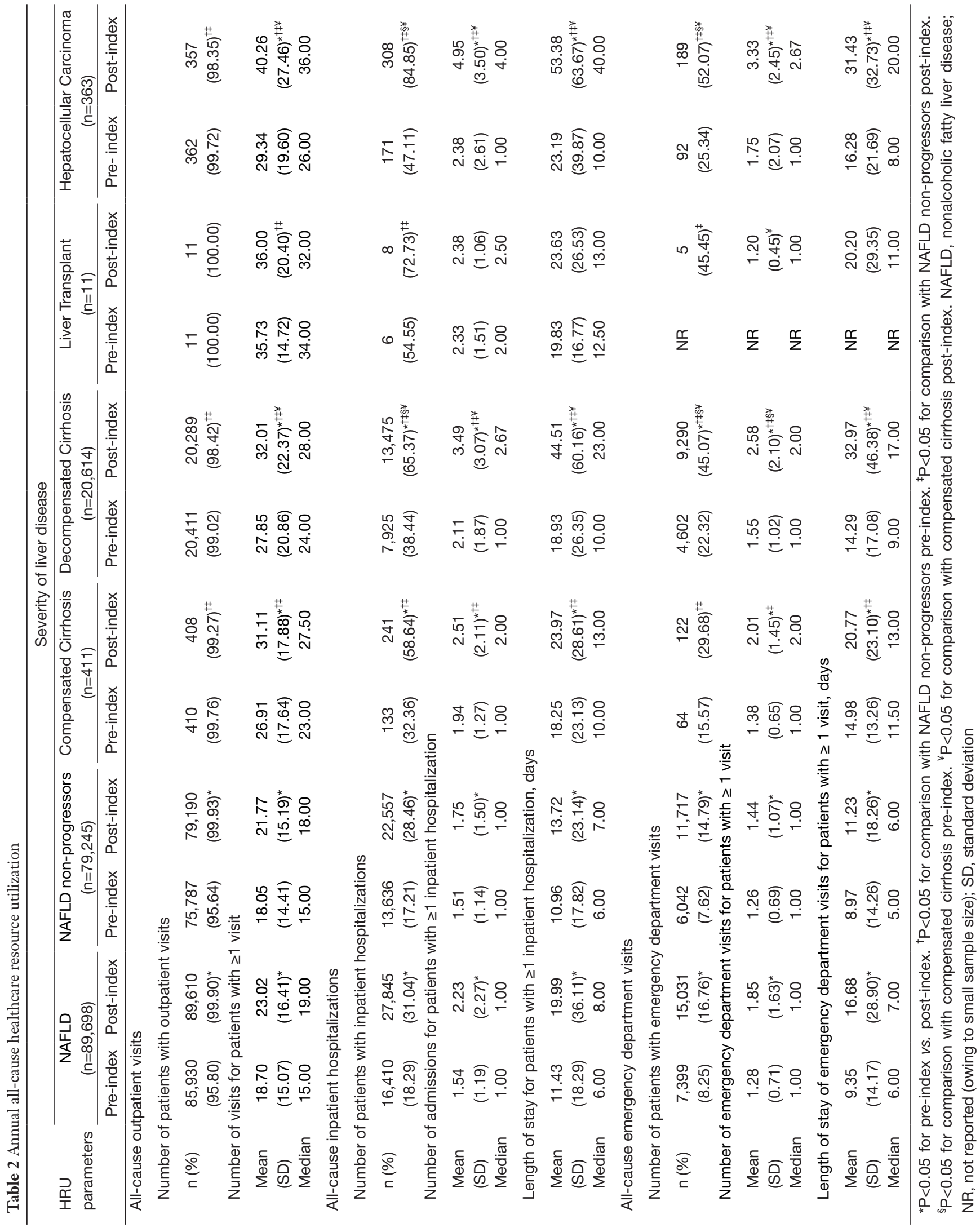




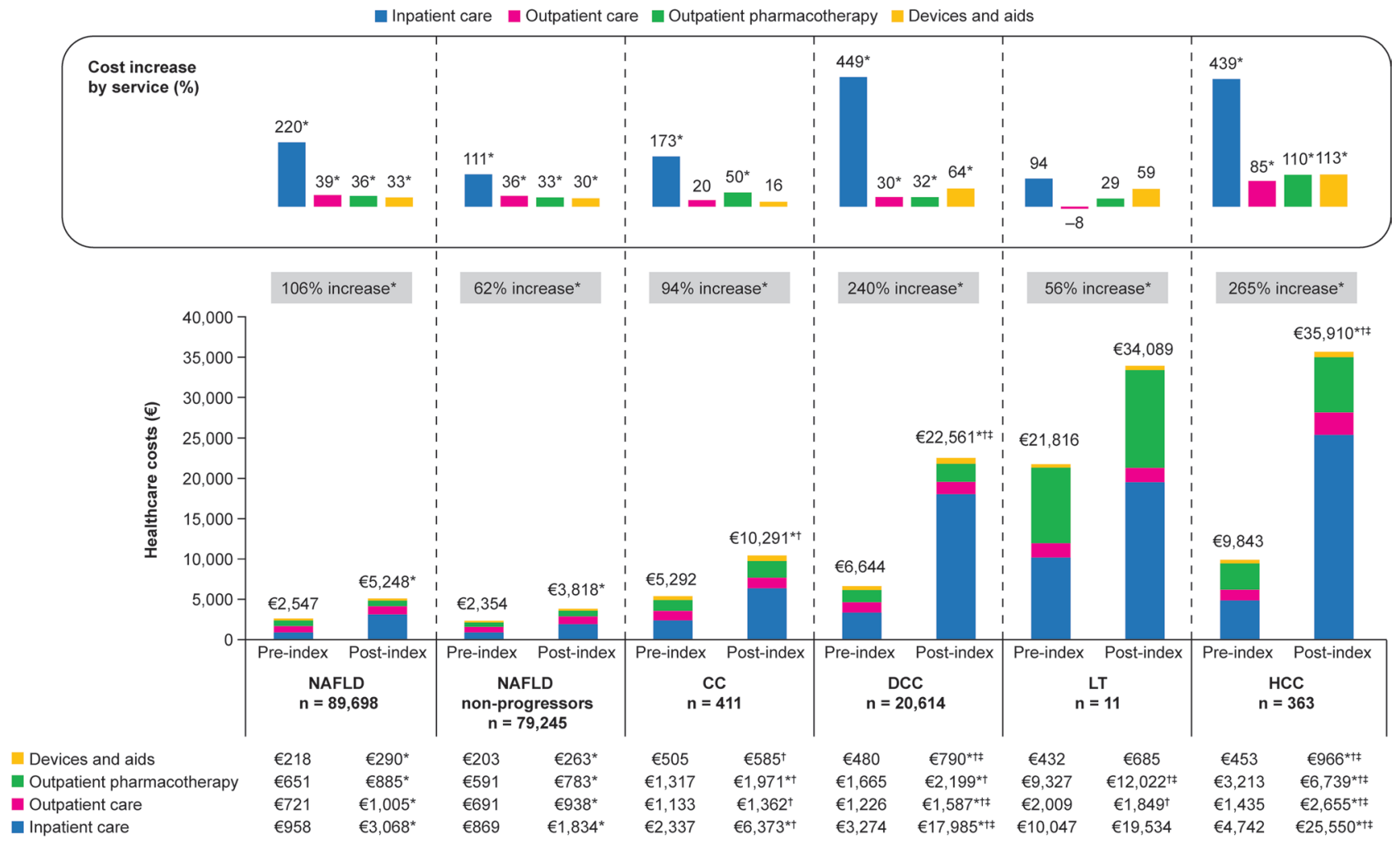

Figure 3 Annual all-cause healthcare costs. ${ }^{*} \mathrm{P}<0.05$ for pre-index $v$ s. post-index. ${ }^{\dagger} \mathrm{P}<0.05$ for comparison with NAFLD non-progressors post-index. ${ }^{\ddagger} \mathrm{P}<0.05$ for comparison with compensated cirrhosis post-index. CC, compensated cirrhosis; DCC, decompensated cirrhosis; HCC, hepatocellular carcinoma; LT, liver transplant; NAFLD, nonalcoholic fatty liver disease.

Tables S1-S3.

\section{Annual all-cause bealthcare costs}

Following the diagnosis of liver severity stages, the calculated mean annual total healthcare costs increased significantly in all liver severity stages (except for liver transplant) and across most of the healthcare service components (except for outpatient and devices costs in compensated cirrhosis) when compared with the year before the index diagnosis $(\mathrm{P}<0.05)$ (Figure 3).

The healthcare cost increases in the compensated cirrhosis, decompensated cirrhosis, and HCC cohorts were substantial, at $94.47 \%, 239.55 \%$, and $264.82 \%$, respectively $(\mathrm{P}<0.0001)$. The total mean annual post-index costs for NAFLD patients and patients with advanced liver diseases were several times higher than for non-progressors, at $€ 10,291$ (compensated cirrhosis), €22,561 (decompensated cirrhosis), €34,089 (liver transplant), and €35,910 (HCC), compared with $€ 3,818$, per patient $(\mathrm{P}<0.001$, except for the liver transplant cohort, owing to the small sample size (Figure 3).

Inpatient costs were found to be the major contributor to total healthcare costs, ranging from $48.04 \%$ for nonprogressors to $79.72 \%$ for patients with decompensated cirrhosis. Additionally, inpatient costs were found to be the primary drivers of the total cost increment from pre-index to post-index.

All-cause healthcare costs, stratified by type 2 diabetes mellitus, cardiovascular diseases, and renal disease, are presented in Tables S4-S6.

The applied GEE model confirmed significantly increasing post-index costs with increasing liver severity stages (Table 3). Compared with non-progressors, the costs for patients with compensated cirrhosis, decompensated cirrhosis, liver transplant, and HCC were 1.81, 3.68, 16.35, and 7.42 times higher, respectively $(\mathrm{P}<0.001)$, with all other covariates held constant. Other significant predictors for higher healthcare costs included demographic characteristics (age, female sex) and certain comorbidities. Comorbidities 
Table 3 GEE model for adjusted total annual all-cause healthcare costs (post-index)

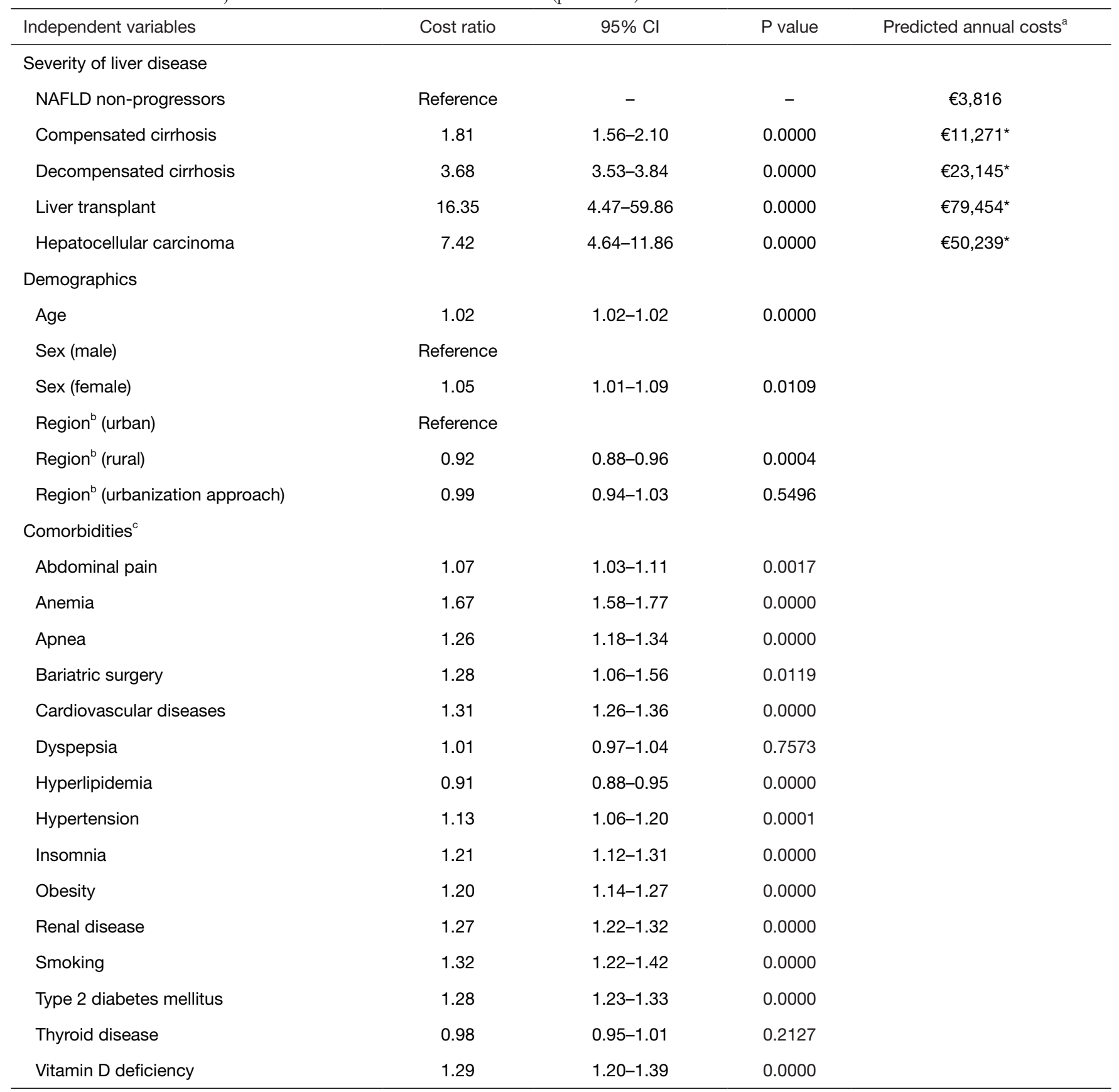

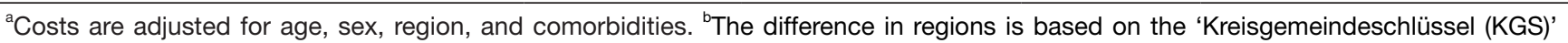
available in the InGef database-The Official Municipality Key is a number sequence for the identification of politically independent municipalities or municipality-free regions in Germany. Therefore, regions can be classified as rural, approaching urbanization, and urban. ${ }^{c}$ Reference group for each comorbidity is patients without the comorbidity. *All comparisons with NAFLD non-progressors were significant at $\mathrm{P}<0.001$. $\mathrm{Cl}$, confidence interval; GEE, generalized estimating equation; NAFLD, nonalcoholic fatty liver disease. 
such as anemia (cost ratio, 1.67), bariatric surgery (1.28), cardiovascular diseases (1.31), type 2 diabetes mellitus (1.28), hypertension (1.13), obesity (1.20), and renal disease (1.27) were associated with increased healthcare costs. However, the presence of hyperlipidemia was associated with reduced healthcare costs $(0.91)$. The annual mean predicted costs were estimated at $€ 3,816$ for non-progressors, $€ 11,271$ for patients with compensated cirrhosis, €23,145 for patients with decompensated cirrhosis, €79,454 for patients with liver transplant, and $€ 50,239$ for patients with HCC.

\section{Discussion}

To the authors' knowledge, this is the first study that provides comprehensive real-world data on the clinical and economic burden of NAFLD patients in Germany using a large population-based cohort. Overall, patients with NAFLD had high and increasing comorbidity burden across progressing liver severity stages. The German patients also incurred high all-cause HRU and costs to the healthcare system, which increased with progressing liver severity stages. After adjusting for baseline demographics and comorbidities, higher all-cause healthcare costs for patients with compensated cirrhosis, decompensated cirrhosis, liver transplant, or HCC versus non-progressors were observed. Furthermore, costs attributable to NAFLD alone were also significant, highlighting the need for targeted interventions in this area.

Our study reported NAFLD prevalence as $4.7 \%$ $(n=215,655)$. When compared against estimates from prior literature (4), this indicates severe underdiagnosis of NAFLD in the real-world medical community of Germany. These findings imply that NAFLD (including $\mathrm{NASH}$ ) remains largely underdiagnosed until the disease progresses to advanced stages. Previous research has shown an association of NAFLD (including NASH) with various comorbidities, including cardiovascular diseases, obesity, type 2 diabetes mellitus, insulin resistance and metabolic syndrome, and chronic kidney disease (20-22). Consistent with these findings, our study reported high comorbidity burden in NAFLD patients. The burden was significantly higher for patients with advanced liver diseases compared with non-progressors. This is not a surprising finding, given the association of metabolic comorbidities with fibrosis progression as evidenced by previous researches (23). Recent real-world studies based on US Medicare claims data (24) or Italian local health units (25) further corroborate the study findings. The presence of concomitant comorbidities may potentially serve as an opportunity to identify patients with NAFLD (including NASH) and associated advanced liver diseases, especially after excluding patients with other etiologies of liver disease.

The economic consequences of untreated German NAFLD patients with advanced liver diseases were also sizeable: a $62-265 \%$ increase in total healthcare costs from pre-index to post-index periods across all liver severity stages, plus the significantly rising costs with progressing liver severity stages. These trends were found to be consistent with findings from previously conducted realworld studies in Europe-in France, hospitalization costs for advanced liver diseases were 1.3-10.7 times higher than for NAFLD (26); in Italy, post-index total healthcare costs in patients with advanced liver diseases were $\geq 86 \%$ higher than in non-progressors, primarily driven by inpatient stays (25); in Spain, post-index total healthcare costs for hospitalized patients with advanced liver disease were $28-168 \%$ higher than for non-progressors (27); in Sweden, total costs incurred by stage 3-4 fibrosis patients were higher than for those with stage 0-2 fibrosis (mean annual costs, $\$ 4,397$ vs. \$629) (28). Moreover, real-world data from the USA were also found to be consistent with these study findings $(24,29)$. A retrospective, single-center study conducted on hepatitis B patients in Germany reported the per-patient annual total costs to be $€ 3,509$. While direct comparison of costs associated with NAFLD or with hepatitis B (or other liver diseases) may not be completely accurate, it is suggestive of NAFLD (including NASH) being potentially more economically burdensome for the healthcare system, especially in the absence of targeted therapies for treatment (30).

Furthermore, the adjusted analysis estimates from the GEE model revealed similar trends to the unadjusted analysis. The fact that the adjusted costs were found to be greater than the unadjusted costs may suggest that most of the total healthcare costs among German patients with NAFLD were primarily driven by the liver-related complications of this disease. As discussed previously, NAFLD patients have a high comorbidity burden. Consequently, the multivariable model reported that most of the comorbid conditions were associated with significantly increased costs. This may be due to the additional management needed to treat the extrahepatic manifestations among patients with NAFLD. In contrast, lower costs associated with hyperlipidemia and thyroid disease may reflect better management strategies for NAFLD (including NASH) patients via statin therapy or 
thyroxin treatment. Hypothyroidism has been associated with various components of the metabolic syndrome, particularly insulin resistance, dyslipidemia, and obesity, and hence may be associated with NAFLD (31). One of the notable findings in this study was that majority of the patients ( 98\%) already had decompensated cirrhosis at the first diagnosis of cirrhosis (compensated plus decompensated). Not only is this finding highly consistent with previous real-world studies $(24,25,29)$, it is also of significant interest as it indicates gross underdiagnosis of compensated cirrhosis. There could be a missed opportunity to identify these patients during the early stages of disease progression. Yet again, this highlights the absence of accurate screening methods or reliable indicators for NAFLD (including NASH) and the need for effective therapeutic intervention.

Although this is the first real-world study on NAFLD patients in Germany that analyzes a large, populationbased cohort with longitudinal data, allowing adequate time to assess disease progression, there are certain limitations that should be considered while interpreting the study results. The analyses were restricted to the InGef research database, which may not be representative of the whole German population. However, this database is extensive and includes approximately two-thirds of all statutory health insurances in Germany. The identification of patients with NAFLD (including NASH) and advanced liver diseases (particularly compensated cirrhosis) was limited to the use of ICD-10-GM codes owing to lack of laboratory data or other measures of fibrosis in the InGef claims database, which may have caused an underestimation of the true number of patients with NAFLD or those with disease progression, especially if asymptomatic (i.e., progressing from compensated cirrhosis to HCC).

The identified patients in the advanced liver disease stages could have had a more severe diagnosis in the time before the NAFLD index quarter; this could not be ruled out owing to patient flow and sample size limitations. The NAFLD non-progressor group might have included patients with stage F0-F3 disease, as well as those with undiagnosed stage F4 (CC), owing to under-coding and the lack of ICD codes for stages F0-F3. Patients with a diagnosis (ICD-10-GM codes) of alcoholism were excluded from the study; however, a lack of information on the level of alcohol consumption/blood alcohol levels may not have excluded these patients accurately. Adjustment of characteristics in the multivariable analyses was limited to those that could be measured using the available data. This may have led to residual confounding. The study focused on direct costs only. The analysis did not assess indirect costs associated with NAFLD such as lost productivity or diminished quality of life, that should be accounted for in future studies. Lastly, any interpretation of results from subgroups with small number of cases (i.e., liver transplant recipients; $\mathrm{n}=11$ ) should be treated with caution.

\section{Conclusions}

This study highlighted that NAFLD patients in Germany are profoundly underdiagnosed, associated with substantial comorbidity burden and incur a significant economic burden on the healthcare system. Results suggest a pressing need for early identification methods and effective therapies among NAFLD, including the high-risk NASH patients, which could reduce the risk of disease progression as well as limit the burgeoning costs in Germany.

\section{Acknowledgments}

Writing assistance was provided by Gemma Carter, $\mathrm{PhD}$ of Oxford PharmaGenesis in accordance with Good Publication Practice and financially supported by Gilead Sciences, Inc.

Funding: This study was financially supported by Gilead Sciences, Inc.

\section{Footnote}

Reporting Checklist: The authors have completed the STROBE reporting checklist. Available at http://dx.doi. org/10.21037/atm-20-7179

Data Sharing Statement: Available at http://dx.doi. org/10.21037/atm-20-7179

Conflicts of Interest: All authors have completed the ICMJE uniform disclosure form (available at http://dx.doi. org/10.21037/atm-20-7179). AC is consultant for Alexion Pharmaceuticals Inc., Gilead Sciences Inc. and speaker for Sanofi, Takeda, Falk-Foundation, Merz. NK is employee and stockholder of Gilead Sciences, Inc. JSH and DM are employees of Xcenda $\mathrm{GmbH}$ and received funding from Gilead Sciences Inc. to conduct the study analyses. The analyses were performed in collaboration with Prof. Dr. Wolfgang Greiner and the Institut für angewandte Gesundheitsforschung (InGef). ABO was an employee and 
stockholder of Gilead Sciences, Inc. at the time of the study. JPS has no conflicts of interest to declare.

Ethical Statement: The authors are accountable for all aspects of the work in ensuring that questions related to the accuracy or integrity of any part of the work are appropriately investigated and resolved. All patient-level data in the InGef database are de-identified to comply with German data protection regulations and German Federal Law; therefore, the study did not require approval from an institutional review board or ethics committee. The study conformed to the Declaration of Helsinki (as revised in 2013), since no research on humans was performed.

Open Access Statement: This is an Open Access article distributed in accordance with the Creative Commons Attribution-NonCommercial-NoDerivs 4.0 International License (CC BY-NC-ND 4.0), which permits the noncommercial replication and distribution of the article with the strict proviso that no changes or edits are made and the original work is properly cited (including links to both the formal publication through the relevant DOI and the license). See: https://creativecommons.org/licenses/by-nc-nd/4.0/.

\section{References}

1. Younossi Z, Anstee QM, Marietti M, et al. Global burden of NAFLD and NASH: trends, predictions, risk factors and prevention. Nat Rev Gastroenterol Hepatol 2018;15:11-20.

2. Younossi ZM, Koenig AB, Abdelatif D, et al. Global epidemiology of nonalcoholic fatty liver disease-Metaanalytic assessment of prevalence, incidence, and outcomes. Hepatology 2016;64:73-84.

3. Blachier M, Leleu H, Peck-Radosavljevic M, et al. The burden of liver disease in Europe: a review of available epidemiological data. J Hepatol 2013;58:593-608.

4. Haring R, Wallaschofski H, Nauck M, et al. Ultrasonographic hepatic steatosis increases prediction of mortality risk from elevated serum gamma-glutamyl transpeptidase levels. Hepatology 2009;50:1403-11.

5. Younossi Z, Henry L. Contribution of Alcoholic and Nonalcoholic Fatty Liver Disease to the Burden of LiverRelated Morbidity and Mortality. Gastroenterology 2016;150:1778-85.

6. Dulai PS, Singh S, Patel J, et al. Increased risk of mortality by fibrosis stage in nonalcoholic fatty liver disease: Systematic review and meta-analysis. Hepatology
2017;65:1557-65.

7. Younossi ZM, Stepanova M, Henry L, et al. A diseasespecific quality of life instrument for non-alcoholic fatty liver disease and non-alcoholic steatohepatitis: CLDQNAFLD. Liver Int 2017;37:1209-18.

8. Weiss J, Rau M, Geier A. Non-alcoholic fatty liver disease: epidemiology, clinical course, investigation, and treatment. Dtsch Arztebl Int 2014;111:447-52.

9. Kothari S, Dhami-Shah H, Shah SR. Antidiabetic drugs and statins in nonalcoholic fatty liver disease. J Clin Exp Hepatol 2019;9:723-30.

10. Hardy T, Anstee QM, Day CP. Nonalcoholic fatty liver disease: new treatments. Curr Opin Gastroenterol 2015;31:175-83.

11. Younossi ZM, Blissett D, Blissett R, et al. The economic and clinical burden of nonalcoholic fatty liver disease in the United States and Europe. Hepatology 2016;64:1577-86.

12. Phisalprapa $P$, Supakankunti S, Charatcharoenwitthaya $\mathrm{P}$, et al. Cost-effectiveness analysis of ultrasonography screening for nonalcoholic fatty liver disease in metabolic syndrome patients. Medicine (Baltimore) 2017;96:e6585.

13. Klebanoff MJ, Corey KE, Chhatwal J, et al. Bariatric surgery for nonalcoholic steatohepatitis: A clinical and cost-effectiveness analysis. Hepatology 2017;65:1156-64.

14. Corey KE, Klebanoff MJ, Tramontano AC, et al. Screening for Nonalcoholic Steatohepatitis in Individuals with Type 2 Diabetes: A Cost-Effectiveness Analysis. Dig Dis Sci 2016;61:2108-17.

15. Andersohn F, Walker J. Characteristics and external validity of the German Health Risk Institute (HRI) Database. Pharmacoepidemiol Drug Saf 2016;25:106-9.

16. Haas J, Braun S, Wutzler P. Burden of influenza in Germany: a retrospective claims database analysis for the influenza season 2012/2013. Eur J Health Econ 2016;17:669-79.

17. Ziemssen T, Prosser C, Haas JS, et al. Healthcare resource use and costs of multiple sclerosis patients in Germany before and during fampridine treatment. BMC Neurol 2017;17:62.

18. Spitzenverband G. Statutory health insurance. Available online: https://www.gkv-spitzenverband. de/krankenversicherung/kv_grundprinzipien/alle_ gesetzlichen_krankenkassen/alle_gesetzlichen_ krankenkassen.jsp

19. Rockey DC, Caldwell SH, Goodman ZD, et al. Liver biopsy. Hepatology 2009;49:1017-44.

20. Adams LA, Anstee QM, Tilg H, et al. Non-alcoholic fatty 
liver disease and its relationship with cardiovascular disease and other extrahepatic diseases. Gut 2017;66:1138-53.

21. Ahmed A, Wong RJ, Harrison SA. Nonalcoholic Fatty Liver Disease Review: Diagnosis, Treatment, and Outcomes. Clin Gastroenterol Hepatol 2015;13:2062-70.

22. Lazo M, Hernaez R, Eberhardt MS, et al. Prevalence of nonalcoholic fatty liver disease in the United States: the Third National Health and Nutrition Examination Survey, 1988-1994. Am J Epidemiol 2013;178:38-45.

23. Wong VW, Wong GL, Choi PC, et al. Disease progression of non-alcoholic fatty liver disease: a prospective study with paired liver biopsies at 3 years. Gut 2010;59:969-74.

24. Gordon SC, Fraysse J, Li S, et al. Disease severity is associated with higher healthcare utilization in nonalcoholic steatohepatitis medicare patients. Am J Gastroenterol 2020;115:562-74.

25. Petta S, Ting J, Saragoni S, et al. Healthcare resource utilization and costs of nonalcoholic steatohepatitis patients with advanced liver disease in Italy. Nutr Metab Cardiovasc Dis 2020;30:1014-22.

26. Boursier J, Fraysse J, Lafuma A, et al. PS-059-Increased healthcare resource utilization and costs in nonalcoholic

Cite this article as: Canbay A, Kachru N, Haas JS, Meise D, Ozbay AB, Sowa JP. Healthcare resource utilization and costs among nonalcoholic fatty liver disease patients in Germany. Ann Transl Med 2021;9(8):615. doi: 10.21037/atm-20-7179 fatty liver disease/non-alcoholic steatohepatitis patients with liver disease progression: a multivariate analysis of French national hospital care. J Hepatol 2019;70:e36.

27. Gomez MR, Kachru N, Ozbay AB, et al. SAT-105-Rising economic burden following the diagnosis of compensated cirrhosis among hospitalized patients with Non-alcoholic fatty liver disease/non-alcoholic steatohepatitis in Spain. J Hepatol 2019;70:e675.

28. Hagstrom H, Nasr P, Ekstedt M, et al. Health care costs of patients with biopsy-confirmed nonalcoholic fatty liver disease are nearly twice those of matched controls. Clin Gastroenterol Hepatol 2020;18:1592-9.e8.

29. Gordon S, Kachru N, Sanatan S, et al. More than 4 times higher healthcare costs for end-stage liver disease patients with non-alcoholic fatty liver disease/non-alcoholic steatohepatitis. J Hepatol 2019;70:e295-6.

30. Stahmeyer JT, Becker H, Orlemann AL, et al. HBVinfections in Germany - health care costs in a real-lifesetting. Z Gastroenterol 2017;55:1103-12.

31. Pagadala MR, Zein CO, Dasarathy S, et al. Prevalence of hypothyroidism in nonalcoholic fatty liver disease. Dig Dis Sci 2012;57:528-34. 


\section{Classifying Patients into Disease Severity Cohorts}

The first diagnosis of NAFLD marked the NAFLD index quarter.

Patients with NAFLD index quarter, having continuous enrollment for 1 year before and after the index quarter and no evidence of NAFLD or advanced liver disease within 1 year preceding the index quarter constituted the 'NAFLD' cohort.

Out of them, patients who were not diagnosed with any advanced liver disease at any time during the study period were categorized as 'NAFLD non-progressors'.

Following the NAFLD index quarter, the subsequent first diagnosis of a more severe stage marked the index quarter for that stage (stage-specific index quarter). The diagnosis of disease severity stages was based on the presence of $\geq 1$ ICD-10-GM or OPS (Operationen-und Prozedurenschlüssel [German procedure classification] or DRG (Diagnosis Related Group) codes.

Patients were included in $\geq 1$ disease severity stage, if they had (i) continuous enrollment for 1 year before and after the stage-specific index quarter, and (ii) no evidence of more severe stage in the 1 year preceding the stage-specific index quarter.

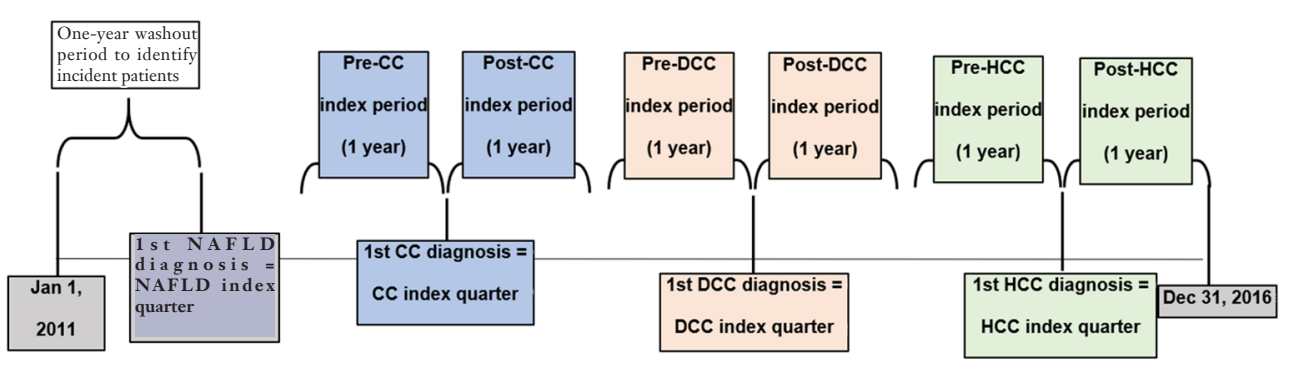

Figure S1 Study schema. LT index quarter was captured in a similar manner. CC: compensated cirrhosis; DCC: decompensated cirrhosis; HCC: hepatocellular carcinoma; LT: liver transplant; NAFLD: nonalcoholic fatty liver disease.

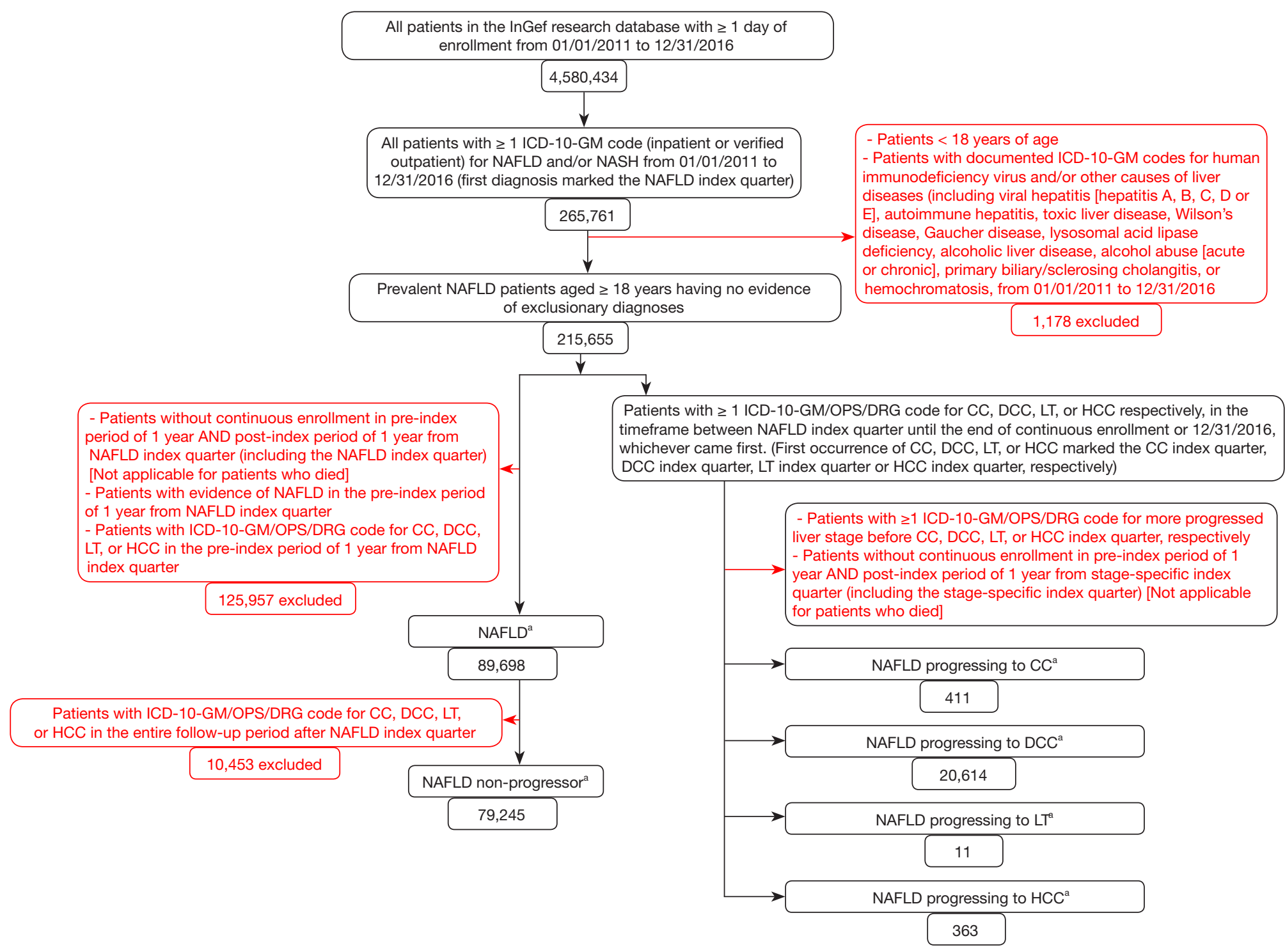

Figure S2 Detailed patient attrition. ${ }^{2}$ Liver disease severity cohorts are not mutually exclusive because patients are included in >1 severity cohort. CC: compensated cirrhosis; DCC: decompensated cirrhosis; DRG: Diagnosis Related Group; HCC: hepatocellular carcinoma; ICD-10-GM: International Classification of Diseases, Tenth Edition, German Modification; InGef: Institut für angewandte Gesundheitsforschung; LT: liver transplantation; NAFLD: nonalcoholic fatty liver disease; NASH: nonalcoholic steatohepatitis; OPS: Operationen-und Prozedurenschlüssel (German procedure classification). 


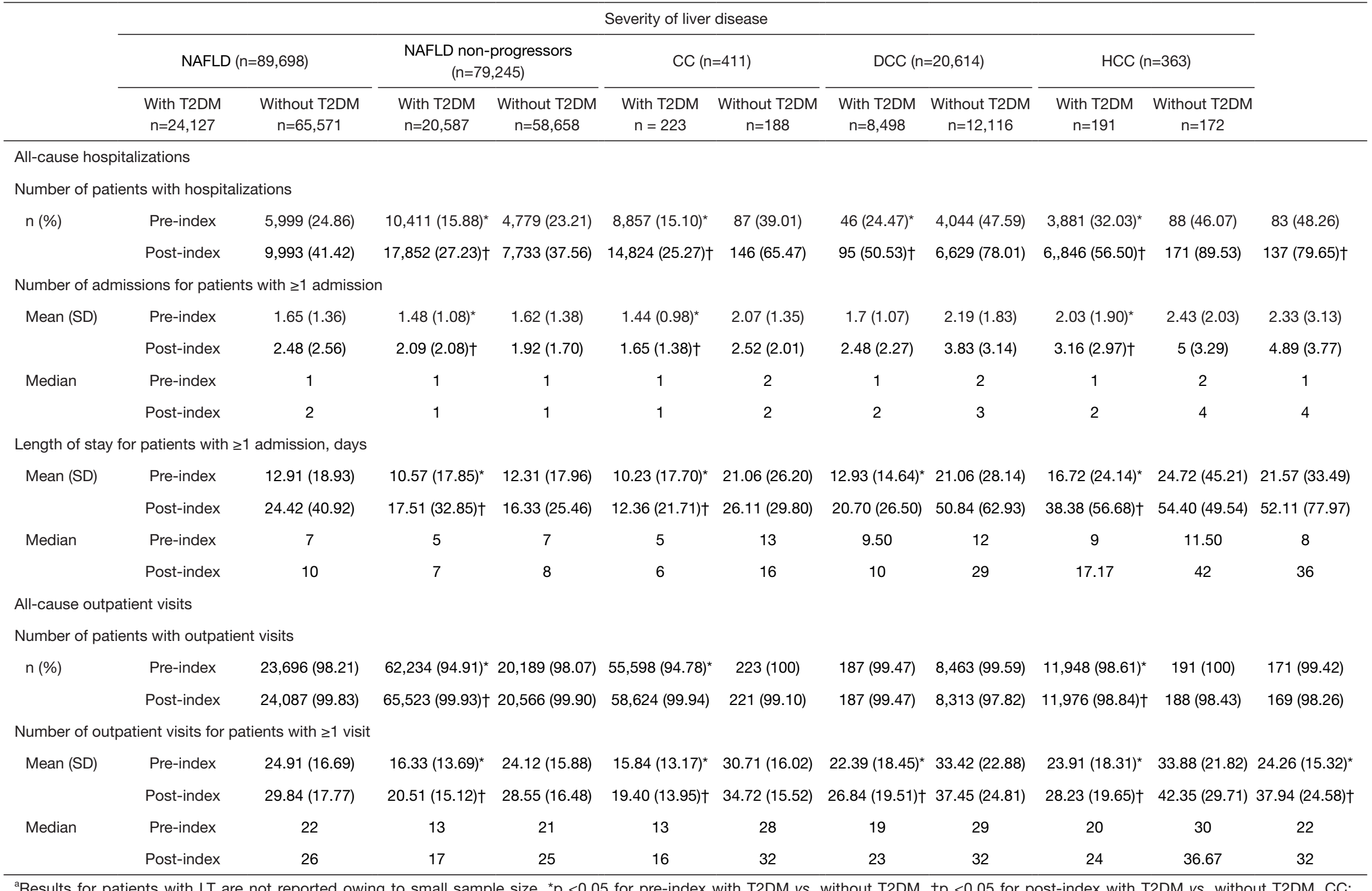

${ }^{a}$ Results for patients with LT are not reported owing to small sample size. ${ }^{*} \mathrm{p}<0.05$ for pre-index with T2DM vs. without T2DM. †p $<0.05$ for post-index with T2DM vs. without T2DM. CC: compensated cirrhosis; DCC: decompensated cirrhosis; LT: liver transplantation; NAFLD: nonalcoholic fatty liver disease; SD: standard deviation; T2DM: type 2 diabetes mellitus.

Table S2 Annual all-cause healthcare resource utilization, stratified by CVD

\begin{tabular}{|c|c|c|c|c|c|c|c|c|c|c|c|}
\hline & \multicolumn{10}{|c|}{ Severity of liver disease } & \\
\hline & \multicolumn{2}{|c|}{$\operatorname{NAFLD~}(n=89,698)$} & \multicolumn{2}{|c|}{$\begin{array}{l}\text { NAFLD non-progressors } \\
\qquad(\mathrm{n}=79,245)\end{array}$} & \multicolumn{2}{|c|}{$C C(n=411)$} & \multicolumn{2}{|c|}{ DCC $(n=20,614)$} & \multicolumn{2}{|c|}{$\mathrm{HCC}(\mathrm{n}=363)$} & \\
\hline & $\begin{array}{l}\text { With CVD } \\
\mathrm{n}=36,412\end{array}$ & $\begin{array}{l}\text { Without CVD } \\
n=53,286\end{array}$ & $\begin{array}{l}\text { With CVD } \\
n=30,525\end{array}$ & $\begin{array}{c}\text { Without CVD } \\
n=48,720\end{array}$ & $\begin{array}{l}\text { With CVD } \\
\mathrm{n}=257\end{array}$ & $\begin{array}{l}\text { Without CVD } \\
n=154\end{array}$ & $\begin{array}{l}\text { With CVD } \\
n=13,943\end{array}$ & $\begin{array}{c}\text { Without CVD } \\
n=6,671\end{array}$ & $\begin{array}{c}\text { With CVD } \\
n=246\end{array}$ & $\begin{array}{l}\text { Without CVD } \\
n=117\end{array}$ & \\
\hline \multicolumn{12}{|c|}{ All-cause hospitalizations } \\
\hline \multicolumn{12}{|c|}{ Number of patients with hospitalizations } \\
\hline \multirow[t]{2}{*}{$\mathrm{n}(\%)$} & Pre-index & $9,875(27.12)$ & $6,535(12.26)^{\star}$ & $7,832(25.66)$ & $5,804(11.91)^{\star}$ & $102(39.69)$ & $31(20.13)^{\star}$ & $6,493(46.57)$ & $1,432(21.47)^{\star}$ & $129(52.44)$ & $42(35.90)^{\star}$ \\
\hline & Post-index & $16,120(44.27)$ & $11,725(22) \dagger$ & $12,411(40.66)$ & $10,146(20.83) \dagger$ & $168(65.37)$ & $73(47.40) \dagger$ & $10,657(76.43)$ & $2,818(42.24) \dagger$ & $221(89.84)$ & $87(74.36) \dagger$ \\
\hline \multicolumn{12}{|c|}{ Number of admissions for patients with $\geq 1$ admission } \\
\hline \multirow[t]{2}{*}{ Mean (SD) } & Pre-index & $1.64(1.23)$ & $1.39(1.11)^{\star}$ & $1.60(1.18)$ & $1.37(1.08)^{\star}$ & $2.05(1.32)$ & $1.58(0.99)^{*}$ & $2.16(1.81)$ & $1.92(2.09)^{*}$ & $2.44(2.82)$ & $2.19(1.85)$ \\
\hline & Post-index & $2.52(2.50)$ & $1.83(1.85) \dagger$ & $1.94(1.63)$ & $1.50(1.28) \dagger$ & $2.78(2.12)$ & $1.88(1.97) \dagger$ & $3.74(3.09)$ & $2.54(2.83) \dagger$ & $5.17(3.66)$ & $4.40(3.01)$ \\
\hline \multirow[t]{2}{*}{ Median } & Pre-index & 1 & 1 & 1 & 1 & 2 & 1 & 2 & 1 & 1 & 1 \\
\hline & Post-index & 2 & 1 & 1 & 1 & 2 & 1 & 3 & 1 & 4 & 4 \\
\hline \multicolumn{12}{|c|}{ Length of stay for patients with $\geq 1$ admission, days } \\
\hline \multirow[t]{2}{*}{ Mean (SD) } & Pre-index & $12.32(17.82)$ & $10.08(18.90)^{\star}$ & $11.82(17.55)$ & $9.79(18.11)^{\star}$ & $19.79(23.47)$ & $13.16(21.58)$ & $19.83(26.54)$ & $14.87(25.04)^{\star}$ & $22.95(41.90)$ & $23.9(33.30)$ \\
\hline & Post-index & $24.12(39.86)$ & $14.31(29.26) \dagger$ & $15.93(24.79)$ & $11.01(20.63) \dagger$ & $27.62(30.81)$ & $15.58(20.59) \dagger$ & $49.20(62.32)$ & $26.78(47.15) \dagger$ & $54.08(45.83)$ & $51.61(95.35)$ \\
\hline \multirow[t]{2}{*}{ Median } & Pre-index & 7 & 5 & 6 & 5 & 12.50 & 7 & 11 & 7 & 10 & 8 \\
\hline & Post-index & 10 & 6 & 8 & 5 & 17 & 7 & 28 & 10 & 44 & 26 \\
\hline \multicolumn{12}{|c|}{ All-cause outpatient visits } \\
\hline \multicolumn{12}{|c|}{ Number of patients with outpatient visits } \\
\hline \multirow[t]{2}{*}{$\mathrm{n}(\%)$} & Pre-index & $35,718(98.09)$ & $50,212(94.23)^{*}$ & 29,922 (98.02) & $45,865(94.14)^{\star}$ & $256(99.61)$ & $154(100)$ & $13,863(99.43)$ & $6,548(98.16)^{\star}$ & $246(100)$ & 116 (99.15) \\
\hline & Post-index & $36,352(99.84)$ & $53,258(99.95) \dagger$ & $30,494(99.90)$ & 48,696 (99.95)† & $255(99.22)$ & $153(99.35)$ & $13,650(97.90)$ & $6,639(99.52) \dagger$ & $242(98.37)$ & $115(98.29)$ \\
\hline \multicolumn{12}{|c|}{ Number of outpatient visits for patients with $\geq 1$ visit } \\
\hline \multirow[t]{2}{*}{ Mean (SD) } & Pre-index & 23.82 (16.90) & $15.06(12.41)^{\star}$ & $23.01(16.05)$ & $14.81(12.19)^{\star}$ & $30.30(19.02)$ & $21.29(13.35)^{\star}$ & 31.36 (21.98) & $20.42(15.89)^{\star}$ & $31.85(20.34)$ & $24.01(16.80)^{\star}$ \\
\hline & Post-index & 28.81 (18.25) & $19.07(13.68) \dagger$ & $27.36(16.84)$ & $18.28(12.88) \dagger$ & $34.42(19.43)$ & $25.59(13.27) \dagger$ & $35.62(23.77)$ & $24.59(16.92) \dagger$ & $42.76(29.42)$ & $35.01(21.98) \dagger$ \\
\hline \multirow[t]{2}{*}{ Median } & Pre-index & 21 & 12 & 20 & 12 & 27 & 19 & 27 & 17 & 29 & 22 \\
\hline & Post-index & 25 & 16 & 24 & 15 & 32 & 24 & 31 & 21 & 38.33 & 29 \\
\hline
\end{tabular}

${ }^{a}$ Results for patients with $\mathrm{LT}$ are not reported owing to small sample size. ${ }^{*} \mathrm{p}<0.05$ for pre-index with CVD vs. without CVD. $\nmid \mathrm{p}<0.05$ for post-index with CVD vs. without CVD. CC: compensated cirrhosis; CVD: cardiovascular diseases; DCC: decompensated cirrhosis; LT: liver transplantation; NAFLD: nonalcoholic fatty liver disease; SD: standard deviation. 


\begin{tabular}{|c|c|c|c|c|c|c|c|c|c|c|c|}
\hline & \multicolumn{10}{|c|}{ Severity of liver disease } & \\
\hline & \multicolumn{2}{|c|}{$\operatorname{NAFLD}(n=89,698)$} & \multicolumn{2}{|c|}{$\begin{array}{l}\text { NAFLD non-progressors } \\
\quad(n=79,245)\end{array}$} & \multicolumn{2}{|c|}{$\operatorname{CC}(n=411)$} & \multicolumn{2}{|c|}{$\operatorname{DCC}(n=20,614)$} & \multicolumn{2}{|c|}{ HCC $(n=363)$} & \\
\hline & $\begin{array}{c}\text { With renal } \\
\text { disease } \\
n=22,108\end{array}$ & $\begin{array}{c}\text { Without renal } \\
\text { disease } \\
n=67,590\end{array}$ & $\begin{array}{c}\text { With renal } \\
\text { disease } \\
n=18,289\end{array}$ & $\begin{array}{l}\text { Without renal } \\
\text { disease } \\
n=60,956\end{array}$ & $\begin{array}{c}\text { With renal } \\
\text { disease } \\
n=182\end{array}$ & $\begin{array}{l}\text { Without renal } \\
\text { disease } \\
n=229\end{array}$ & $\begin{array}{l}\text { With renal } \\
\text { disease } \\
\mathrm{n}=9,977\end{array}$ & $\begin{array}{l}\text { Without renal } \\
\text { disease } \\
n=10,637\end{array}$ & $\begin{array}{c}\text { With renal } \\
\text { disease } \\
\mathrm{n}=197\end{array}$ & $\begin{array}{l}\text { Without renal } \\
\text { disease } \\
n=166\end{array}$ & \\
\hline \multicolumn{12}{|c|}{ All-cause hospitalizations } \\
\hline \multicolumn{12}{|c|}{ Number of patients with hospitalizations } \\
\hline \multirow[t]{2}{*}{$n(\%)$} & Pre-index & $6,251(28.27)$ & $10,159(15.03)^{\star}$ & $4,828(26.40)$ & $8,808(14.45)^{\star}$ & 74 (40.66) & $59(25.76)^{\star}$ & $4,977(49.88)$ & $2,948(27.71)^{\star}$ & $103(52.28)$ & $68(40.96)^{\star}$ \\
\hline & Post-index & $10,242(46.33)$ & $17,603(26.04) \dagger$ & $7,712(42.17)$ & $14,845(24.35) \dagger$ & $126(69.23)$ & $115(50.22) \dagger$ & $8,004(80.22)$ & $5,471(51.43) \dagger$ & $183(92.89)$ & $125(75.30) \dagger$ \\
\hline \multicolumn{12}{|c|}{ Number of admissions for patients with $\geq 1$ admission } \\
\hline \multirow[t]{2}{*}{ Mean (SD) } & Pre-index & $1.74(1.36)$ & $1.42(1.06)^{\star}$ & $1.70(1.31)$ & $1.40(1.02)^{*}$ & $2.31(1.38)$ & $1.47(0.92)^{\star}$ & $2.26(1.89)$ & $1.86(1.81)^{\star}$ & $2.64(2.95)$ & $1.99(1.94)$ \\
\hline & Post-index & $2.74(2.67)$ & $1.93(1.95) \dagger$ & $2.08(1.79)$ & $1.57(1.29) \dagger$ & $3.11(2.59)$ & $1.85(1.11) \dagger$ & $4.06(3.15)$ & $2.65(2.76) \dagger$ & $5.14(3.53)$ & $4.67(3.47)$ \\
\hline \multirow[t]{2}{*}{ Median } & Pre-index & 1 & 1 & 1 & 1 & 2 & 1 & 2 & 1 & 2 & 1 \\
\hline & Post-index & 2 & 1 & 1 & 1 & 2 & 2 & 3 & 2 & 4 & 4 \\
\hline \multicolumn{12}{|c|}{ Length of stay for patients with $\geq 1$ admission, days } \\
\hline \multirow[t]{2}{*}{ Mean (SD) } & Pre-index & $13.57(18.90)$ & $10.11(17.77)^{\star}$ & $13.03(18.75)$ & $9.83(17.18)^{\star}$ & $23.89(23.94)$ & $11.17(20.12)^{\star}$ & $21.59(27.62)$ & $14.44(23.37)^{\star}$ & $26.61(46.41)$ & $18(26.63)$ \\
\hline & Post-index & $27.76(44.77)$ & $15.47(29) \dagger$ & $18.02(28.31)$ & $11.48(19.56) \dagger$ & $31.39(33.21)$ & $15.84(19.65) \dagger$ & $55.63(66.73)$ & $28.25(44.22) \dagger$ & $57.95(71.17)$ & $46.70(50.26)$ \\
\hline \multirow[t]{2}{*}{ Median } & Pre-index & 8 & 5 & 7 & 5 & 16 & 6 & 13 & 7 & 12 & 7 \\
\hline & Post-index & 11 & 7 & 9 & 6 & 21 & 8 & 34 & 12 & 45 & 30 \\
\hline \multicolumn{12}{|c|}{ All-cause outpatient visits } \\
\hline \multicolumn{12}{|c|}{ Number of patients with outpatient visits } \\
\hline \multirow[t]{2}{*}{$\mathrm{n}(\%)$} & Pre-index & $21,623(97.81)$ & $64,307(95.14)^{\star}$ & 17,858 (97.64) & $57,929(95.03)^{*}$ & $182(100)$ & $228(99.56)$ & $9,924(99.47)$ & $10,487(98.59)^{\star}$ & $197(100)$ & $165(99.40)$ \\
\hline & Post-index & $22,065(99.81)$ & $67,545(99.93) \dagger$ & 18,267 (99.88) & $60,923(99.95) \dagger$ & $180(98.90)$ & $228(99.56)$ & $9,718(97.40)$ & $10,571(99.38) \dagger$ & $192(97.46)$ & $165(99.40)$ \\
\hline \multicolumn{12}{|c|}{ Number of outpatient visits for patients with $\geq 1$ visit } \\
\hline \multirow[t]{2}{*}{ Mean (SD) } & Pre-index & $24.19(18.30)$ & $16.85(13.32)^{*}$ & $23.21(17.25)$ & $16.46(13.01)^{\star}$ & $31.47(20.50)$ & $23.28(14)^{*}$ & $32.67(23.79)$ & $23.29(16.39)^{\star}$ & $32.13(20.70)$ & $26(17.70)^{\star}$ \\
\hline & Post-index & $29.28(19.84)$ & $20.97(14.54) \dagger$ & 27.68 (18.35) & $20(13.62) \dagger$ & 36.04 (20.36) & $27.22(14.55) \dagger$ & 36.94 (25.88) & $27.48(17.38) \dagger$ & 45.85 (31.34) & $33.76(20.33) \dagger$ \\
\hline \multirow[t]{2}{*}{ Median } & Pre-index & 21 & 14 & 20 & 13 & 29 & 21 & 28 & 20 & 29 & 22 \\
\hline & Post-index & 25 & 18 & 24 & 17 & 33.50 & 24 & 32 & 24 & 40.50 & 30 \\
\hline
\end{tabular}

${ }^{a}$ Results for patients with LT are not reported owing to small sample size. ${ }^{\star} \mathrm{p}<0.05$ for pre-index with renal disease $v s$. without renal disease. $\dagger p<0.05$ for post-index with renal disease vs. without renal disease. CC: compensated cirrhosis; DCC: decompensated cirrhosis; LT: liver transplantation; NAFLD: nonalcoholic fatty liver disease; SD: standard deviation. 
Healthcare service component

\begin{tabular}{|c|c|c|c|c|c|c|c|c|c|c|}
\hline \multirow{3}{*}{ NAFLD $(n=89,698)$} & \multicolumn{10}{|c|}{ Healthcare service component } \\
\hline & \multicolumn{2}{|c|}{ Total costs, $€$} & \multicolumn{2}{|c|}{ Inpatient costs, $€$} & \multicolumn{2}{|c|}{ Outpatient costs, $€$} & \multicolumn{2}{|c|}{ Pharmacy costs, $€$} & \multicolumn{2}{|c|}{ Devices and aids costs, $€$} \\
\hline & $\begin{array}{l}\text { With T2DM } \\
n=24,127\end{array}$ & $\begin{array}{c}\text { Without T2DM } \\
n=65,571\end{array}$ & $\begin{array}{l}\text { With T2DM } \\
n=24,127\end{array}$ & $\begin{array}{c}\text { Without T2DM } \\
n=65,571\end{array}$ & $\begin{array}{l}\text { With T2DM } \\
n=24,127\end{array}$ & $\begin{array}{c}\text { Without T2DM } \\
n=65,571\end{array}$ & $\begin{array}{l}\text { With T2DM } \\
\mathrm{n}=24,127\end{array}$ & $\begin{array}{c}\text { Without T2DM } \\
n=65,571\end{array}$ & $\begin{array}{l}\text { With T2DM } \\
\mathrm{n}=24,127\end{array}$ & $\begin{array}{c}\text { Without T2DM } \\
\quad \mathrm{n}=65,571\end{array}$ \\
\hline \multicolumn{11}{|l|}{ Pre-index } \\
\hline Mean (SD) & $\begin{array}{l}3,857.44 \\
(6,350.20)\end{array}$ & $\begin{array}{c}2,064.95 \\
(6,787.56)^{\star}\end{array}$ & $\begin{array}{c}1,438.3 \\
(4,289.13)\end{array}$ & $\begin{array}{c}781.04 \\
(3,183.87)^{\star}\end{array}$ & $\begin{array}{c}969.76 \\
(1,505.12)\end{array}$ & $\begin{array}{c}628.93 \\
(1,040.03)^{\star}\end{array}$ & $\begin{array}{c}1,102.81 \\
(2,773.85)\end{array}$ & $\begin{array}{c}484.72 \\
(5,230.63)^{\star}\end{array}$ & $\begin{array}{c}346.57 \\
(1,068.90)\end{array}$ & $\begin{array}{c}170.27 \\
(1,287.48)^{\star}\end{array}$ \\
\hline Median & $1,877.32$ & 704.80 & 0 & 0 & 712.55 & 409.48 & 501.63 & 93.84 & 46.62 & 0 \\
\hline \multicolumn{11}{|l|}{ Post-index } \\
\hline Mean (SD) & $\begin{array}{c}8,192.37 \\
(23,541.54)\end{array}$ & $\begin{array}{c}4,165.02 \\
(15,899.55) \dagger\end{array}$ & $\begin{array}{c}5,001.61 \\
(22,313.82)\end{array}$ & $\begin{array}{c}2,356.21 \\
(13,964.63) \dagger\end{array}$ & $\begin{array}{c}1,279.29 \\
(1,727.06)\end{array}$ & $\begin{array}{c}903.96 \\
(1,271.10) \dagger\end{array}$ & $\begin{array}{c}1,436.27 \\
(3,669.19)\end{array}$ & $\begin{array}{c}682.45 \\
(5,634.99) \dagger\end{array}$ & $\begin{array}{c}475.20 \\
(2,135.17)\end{array}$ & $\begin{array}{c}222.39 \\
(1,413.46) \dagger\end{array}$ \\
\hline Median & $3,030.56$ & $1,174.36$ & 0 & 0 & 942.51 & 621.79 & 652.87 & 129.59 & 78.54 & 0 \\
\hline Percentage increase, $\%^{a}$ & 112.38 & 101.70 & 247.75 & 201.68 & 31.92 & 43.73 & 30.24 & 40.79 & 37.11 & 30.61 \\
\hline \multicolumn{11}{|c|}{ NAFLD non-progressors ( $n=79,245)$} \\
\hline & $\begin{array}{l}\text { With T2DM } \\
n=20,587\end{array}$ & $\begin{array}{c}\text { Without T2DM } \\
n=58,658\end{array}$ & $\begin{array}{l}\text { With T2DM } \\
n=20,587\end{array}$ & $\begin{array}{c}\text { Without T2DM } \\
n=58,658\end{array}$ & $\begin{array}{l}\text { With T2DM } \\
n=20,587\end{array}$ & $\begin{array}{c}\text { Without T2DM } \\
n=58,658\end{array}$ & $\begin{array}{l}\text { With T2DM } \\
\mathrm{n}=20,587\end{array}$ & $\begin{array}{c}\text { Without T2DM } \\
n=58,658\end{array}$ & $\begin{array}{c}\text { With T2DM } \\
\mathrm{n}=20,587\end{array}$ & $\begin{array}{c}\text { Without T2DM } \\
\qquad n=58,658\end{array}$ \\
\hline \multicolumn{11}{|l|}{ Pre-index } \\
\hline Mean (SD) & $\begin{array}{c}3,561.55 \\
(5,801.01)\end{array}$ & $\begin{array}{c}1,929.87 \\
(6,732.87)^{\star}\end{array}$ & $\begin{array}{c}1,305.41 \\
(4,103.71)\end{array}$ & $\begin{array}{c}716.51 \\
(2,865.28)^{*}\end{array}$ & $\begin{array}{c}928.29 \\
(1,345.89)\end{array}$ & $\begin{array}{c}607.24 \\
(980.47)^{\star}\end{array}$ & $\begin{array}{l}1,008.88 \\
(2,276.37)\end{array}$ & $\begin{array}{c}444.44 \\
(5,415.65)^{\star}\end{array}$ & $\begin{array}{l}318.98 \\
(997.04)\end{array}$ & $\begin{array}{c}161.69 \\
(1,329.13)^{\star}\end{array}$ \\
\hline Median & $1,740.67$ & 674.16 & 0 & 0 & 692.54 & 396.53 & 460.54 & 87.73 & 29.45 & 0 \\
\hline \multicolumn{11}{|l|}{ Post-index } \\
\hline Mean (SD) & $\begin{array}{c}5,780.11 \\
(11,151.48)\end{array}$ & $\begin{array}{c}3,129.80 \\
(9,151.21) \dagger\end{array}$ & $\begin{array}{c}2,847.02 \\
(9,205.07)\end{array}$ & $\begin{array}{c}1,478.80 \\
(5,954.89) \dagger\end{array}$ & $\begin{array}{c}1,203.06 \\
(1,545.24)\end{array}$ & $\begin{array}{c}845.13 \\
(1,157.04) \dagger\end{array}$ & $\begin{array}{l}1,304.59 \\
(3,334.31)\end{array}$ & $\begin{array}{c}600.19 \\
(5,685.38) \dagger\end{array}$ & $\begin{array}{c}425.44 \\
(2,103.37)\end{array}$ & $\begin{array}{c}205.67 \\
(1,386.68) \dagger\end{array}$ \\
\hline Median & $2,706.90$ & $1,076.67$ & 0 & 0 & 911.40 & 592.51 & 595.50 & 120.70 & 74.97 & 0 \\
\hline $\begin{array}{l}\text { Percentage } \\
\text { increase, } \%^{\mathrm{a}}\end{array}$ & 62.29 & 62.18 & 118.09 & 106.39 & 29.60 & 39.18 & 29.31 & 35.05 & 33.38 & 27.20 \\
\hline \multicolumn{11}{|l|}{$\mathrm{CC}(\mathrm{n}=411)$} \\
\hline & $\begin{array}{c}\text { With T2DM } \\
n=223\end{array}$ & $\begin{array}{c}\text { Without T2DM } \\
n=188\end{array}$ & $\begin{array}{l}\text { With T2DM } \\
n=223\end{array}$ & $\begin{array}{c}\text { Without T2DM } \\
n=188\end{array}$ & $\begin{array}{c}\text { With T2DM } \\
n=223\end{array}$ & $\begin{array}{c}\text { Without T2DM } \\
n=188\end{array}$ & $\begin{array}{c}\text { With T2DM } \\
n=223\end{array}$ & $\begin{array}{c}\text { Without T2DM } \\
n=188\end{array}$ & $\begin{array}{c}\text { With T2DM } \\
n=223\end{array}$ & $\begin{array}{l}\text { Without T2DM } \\
\quad n=188\end{array}$ \\
\hline \multicolumn{11}{|l|}{ Pre-index } \\
\hline Mean (SD) & $\begin{array}{c}6,257.45 \\
(7,665.12)\end{array}$ & $\begin{array}{c}4,146.48 \\
(6,811.04)^{\star}\end{array}$ & $\begin{array}{l}2,990.36 \\
(6,072.44)\end{array}$ & $\begin{array}{c}1,561.83 \\
(4,370.71)^{\star}\end{array}$ & $\begin{array}{l}1,221.07 \\
(940.24)\end{array}$ & $\begin{array}{l}1,028.37 \\
(2,411.04)\end{array}$ & $\begin{array}{l}1,504.84 \\
(2,293.64)\end{array}$ & $\begin{array}{l}1,093.34 \\
(3,983.27)\end{array}$ & $\begin{array}{c}541.17 \\
(1,210.83)\end{array}$ & $\begin{array}{c}462.94 \\
(1,227.84)\end{array}$ \\
\hline Median & $3,389.60$ & $1,482.88$ & 0 & 0 & 950.14 & 673.16 & 713.28 & 270.30 & 82.20 & 63.11 \\
\hline \multicolumn{11}{|l|}{ Post-index } \\
\hline Mean (SD) & $\begin{array}{c}12,285.57 \\
(15,572.17)\end{array}$ & $\begin{array}{c}7,924.85 \\
(12,132.89) \dagger\end{array}$ & $\begin{array}{c}7,910.06 \\
(13,164.06)\end{array}$ & $\begin{array}{c}4,549.01 \\
(8,777.77) \dagger\end{array}$ & $\begin{array}{c}1,433.33 \\
(1,004.89)\end{array}$ & $\begin{array}{l}1,277.35 \\
(2,396.12)\end{array}$ & $\begin{array}{l}2,264.76 \\
(5,420.01)\end{array}$ & $\begin{array}{l}1,623.28 \\
(6,123.38)\end{array}$ & $\begin{array}{c}677.42 \\
(1,590.52)\end{array}$ & $\begin{array}{c}475.21 \\
(1,141.07)\end{array}$ \\
\hline Median & $6,996.02$ & $3,085.10$ & $3,562.11$ & 493.72 & $1,223.91$ & 856.73 & $1,000.20$ & 334.19 & 160.18 & 66.94 \\
\hline Percentage increase, $\%^{\mathrm{b}}$ & 96.34 & 91.12 & 164.52 & 191.26 & 17.38 & 24.21 & 50.50 & 48.47 & 25.18 & 2.65 \\
\hline \multicolumn{11}{|l|}{$\operatorname{DCC}(n=20,614)$} \\
\hline & $\begin{array}{c}\text { With T2DM } \\
\mathrm{n}=8,498\end{array}$ & $\begin{array}{c}\text { Without T2DM } \\
n=12,116\end{array}$ & $\begin{array}{c}\text { With T2DM } \\
n=8,498\end{array}$ & $\begin{array}{c}\text { Without T2DM } \\
n=12,116\end{array}$ & $\begin{array}{c}\text { With T2DM } \\
\mathrm{n}=8,498\end{array}$ & $\begin{array}{c}\text { Without T2DM } \\
n=12,116\end{array}$ & $\begin{array}{c}\text { With T2DM } \\
n=8,498\end{array}$ & $\begin{array}{c}\text { Without T2DM } \\
n=12,116\end{array}$ & $\begin{array}{c}\text { With T2DM } \\
n=8,498\end{array}$ & $\begin{array}{c}\text { Without T2DM } \\
\mathrm{n}=12,116\end{array}$ \\
\hline \multicolumn{11}{|l|}{ Pre-index } \\
\hline Mean (SD) & $\begin{array}{c}8,817.13 \\
(14,360.92)\end{array}$ & $\begin{array}{c}5,120.57 \\
(10,343.94)^{\star}\end{array}$ & $\begin{array}{l}4,404.46 \\
(9,955.16)\end{array}$ & $\begin{array}{c}2,480.54 \\
(7,182.55)^{\star}\end{array}$ & $\begin{array}{c}1,505.55 \\
(2,889.71)\end{array}$ & $\begin{array}{c}1,029.21 \\
(1,720.93)^{\star}\end{array}$ & $\begin{array}{l}2,229.97 \\
(7,346.96)\end{array}$ & $\begin{array}{l}1,268.37 \\
(4,849.2)^{\star}\end{array}$ & $\begin{array}{c}677.15 \\
(1,814.14)\end{array}$ & $\begin{array}{c}342.45 \\
(1,291.18)^{\star}\end{array}$ \\
\hline Median & $4,190.40$ & $1,601.88$ & 82.32 & 0 & 987.69 & 680.88 & 975.38 & 251.41 & 151.45 & 0 \\
\hline \multicolumn{11}{|l|}{ Post-index } \\
\hline Mean (SD) & $\begin{array}{l}30,451.01 \\
(62,138.51)\end{array}$ & $\begin{array}{c}17,027.50 \\
(47,042.50) \dagger\end{array}$ & $\begin{array}{c}24,817.45 \\
(61,137.72)\end{array}$ & $\begin{array}{c}13,192.80 \\
(45,263.57) \dagger\end{array}$ & $\begin{array}{l}1,891.69 \\
(3,467.28)\end{array}$ & $\begin{array}{c}1,373.7 \\
(2,250.90) \dagger\end{array}$ & $\begin{array}{l}2,677.08 \\
(6,900.78)\end{array}$ & $\begin{array}{c}1,864.45 \\
(6,703.18) \dagger\end{array}$ & $\begin{array}{c}1,064.78 \\
(2,549.26)\end{array}$ & $\begin{array}{c}596.56 \\
(2,126.47) \dagger\end{array}$ \\
\hline Median & $13,304.95$ & $3,885.25$ & $8,329.80$ & $1,782.03$ & $1,155.79$ & 895.37 & $1,163.15$ & 328.15 & 255.95 & 75.40 \\
\hline Percentage increase, $\%^{\mathrm{b}}$ & 245.36 & 232.53 & 463.46 & 431.85 & 25.65 & 33.47 & 20.05 & 46.99 & 57.24 & 74.21 \\
\hline \multicolumn{11}{|l|}{$\mathrm{HCC}(\mathrm{n}=363)$} \\
\hline & $\begin{array}{c}\text { With T2DM } \\
n=191\end{array}$ & $\begin{array}{l}\text { Without T2DM } \\
\qquad \mathrm{n}=172\end{array}$ & $\begin{array}{l}\text { With T2DM } \\
\text { n=191 }\end{array}$ & $\begin{array}{c}\text { Without T2DM } \\
\quad n=172\end{array}$ & $\begin{array}{l}\text { With T2DM } \\
n=191\end{array}$ & $\begin{array}{c}\text { Without T2DM } \\
\quad n=172\end{array}$ & $\begin{array}{c}\text { With T2DM } \\
n=191\end{array}$ & $\begin{array}{l}\text { Without T2DM } \\
\qquad \mathrm{n}=172\end{array}$ & $\begin{array}{l}\text { With T2DM } \\
n=191\end{array}$ & $\begin{array}{l}\text { Without T2DM } \\
\quad \mathrm{n}=172\end{array}$ \\
\hline \multicolumn{11}{|l|}{ Pre-index } \\
\hline Mean (SD) & $\begin{array}{c}10,865.18 \\
(22,082.32)\end{array}$ & $\begin{array}{c}8,708.17 \\
(14,673.20)\end{array}$ & $\begin{array}{c}4,983.53 \\
(12,498.09)\end{array}$ & $\begin{array}{c}4,473.52 \\
(10,489.91)\end{array}$ & $\begin{array}{c}1,675.83 \\
(2,674.13)\end{array}$ & $\begin{array}{c}1,167.34 \\
(1,163.37)^{\star}\end{array}$ & $\begin{array}{c}3,653.71 \\
(12,303.03)\end{array}$ & $\begin{array}{l}2,724.58 \\
(8,377.69)\end{array}$ & $\begin{array}{c}552.11 \\
(1,398.71)\end{array}$ & $\begin{array}{c}342.73 \\
(753.06)\end{array}$ \\
\hline Median & $3,930.84$ & $2,955.24$ & 0 & 220.88 & $1,038.34$ & 772.94 & 975.85 & 324.13 & 132.64 & 0 \\
\hline \multicolumn{11}{|l|}{ Post-index } \\
\hline Mean (SD) & $\begin{array}{c}32,733.09 \\
(29,480.10)\end{array}$ & $\begin{array}{c}39,437.87 \\
(119,196.52)\end{array}$ & $\begin{array}{l}21,810.31 \\
(24,378.6)\end{array}$ & $\begin{array}{c}29,702.25 \\
(119,441)\end{array}$ & $\begin{array}{c}2,787.10 \\
(4,397.09)\end{array}$ & $\begin{array}{l}2,508.16 \\
(2,582.83)\end{array}$ & $\begin{array}{c}7,002.21 \\
(13,688.04)\end{array}$ & $\begin{array}{c}6,447.01 \\
(11,763.18)\end{array}$ & $\begin{array}{l}1,133.47 \\
(3,114.28)\end{array}$ & $\begin{array}{c}780.45 \\
(1,446.59)\end{array}$ \\
\hline Median & $26,696.58$ & $23,152.17$ & $18,175.48$ & $12,765.05$ & $1,622.72$ & $1,760.36$ & $1,649.68$ & $1,112.86$ & 335.36 & 207.06 \\
\hline Percentage increase, $\%^{\mathrm{b}}$ & 201.27 & 352.88 & 337.65 & 563.96 & 66.31 & 114.86 & 91.65 & 136.62 & 105.30 & 127.71 \\
\hline
\end{tabular}

${ }^{a}$ Results for patients with LT are not reported owing to small sample size. ${ }^{b}$ Percentage increase from the pre-index to the post-index period. * $\mathrm{p}<0.05$ for pre-index with T2DM vs. without T2DM. tp <0.05 for post-index with T2DM vs. without T2DM. CC: compensated cirrhosis; DCC: decompensated cirrhosis; HCC: hepatocellular carcinoma; LT: liver transplantation; NAFLD: nonalcoholic fatty liver disease; SD: standard deviation; T2DM: type 2 diabetes mellitus. 


\begin{tabular}{|c|c|c|c|c|c|c|c|c|c|c|}
\hline & \multicolumn{10}{|c|}{ Healthcare service component } \\
\hline & \multicolumn{2}{|c|}{ Total costs, $€$} & \multicolumn{2}{|c|}{ Inpatient costs, $€$} & \multicolumn{2}{|c|}{ Outpatient costs, $€$} & \multicolumn{2}{|c|}{ Pharmacy costs, $€$} & \multicolumn{2}{|c|}{ Devices and aids costs, $€$} \\
\hline & $\begin{array}{l}\text { With CVD } \\
n=36,412\end{array}$ & $\begin{array}{c}\text { Without CVD } \\
n=53,286\end{array}$ & $\begin{array}{l}\text { With CVD } \\
\mathrm{n}=36,412\end{array}$ & $\begin{array}{l}\text { Without CVD } \\
n=53,286\end{array}$ & $\begin{array}{l}\text { With CVD } \\
\mathrm{n}=36,412\end{array}$ & $\begin{array}{l}\text { Without CVD } \\
n=53,286\end{array}$ & $\begin{array}{l}\text { With CVD } \\
n=36,412\end{array}$ & $\begin{array}{l}\text { Without CVD } \\
n=53,286\end{array}$ & $\begin{array}{l}\text { With CVD } \\
n=36,412\end{array}$ & $\begin{array}{c}\text { Without CVD } \\
n=53,286\end{array}$ \\
\hline \multicolumn{11}{|l|}{ Pre-index } \\
\hline Mean (SD) & $\begin{array}{c}3,768.80 \\
(6,732.56)\end{array}$ & $\begin{array}{c}1,712.27 \\
(6,582.10)^{\star}\end{array}$ & $\begin{array}{c}1,549.38 \\
(4,471.38)\end{array}$ & $\begin{array}{c}553.60 \\
(2,623.39)^{\star}\end{array}$ & $\begin{array}{c}960.02 \\
(1,646.46)\end{array}$ & $\begin{array}{c}557.01 \\
(690.56)^{\star}\end{array}$ & $\begin{array}{c}937.57 \\
(3,274.26)\end{array}$ & $\begin{array}{c}455.14 \\
(5,464.18)^{*}\end{array}$ & $\begin{array}{c}321.83 \\
(1,069.13)\end{array}$ & $\begin{array}{c}146.53 \\
(1,331.85)^{\star}\end{array}$ \\
\hline Median & $1,681.60$ & 610.40 & 0 & 0 & 690.10 & 368.60 & 338.90 & 77.40 & 26 & 0 \\
\hline \multicolumn{11}{|l|}{ Post-index } \\
\hline Mean (SD) & $\begin{array}{c}8,358.01 \\
(25,376.81)\end{array}$ & $\begin{array}{c}3,123.33 \\
(10,779.71) \dagger\end{array}$ & $\begin{array}{c}5,404.19 \\
(24,129.25)\end{array}$ & $\begin{array}{l}1,471.22 \\
(7,975) \dagger\end{array}$ & $\begin{array}{c}1,279.43 \\
(1,858.43)\end{array}$ & $\begin{array}{c}817.33 \\
(968.81) \dagger\end{array}$ & $\begin{array}{c}1,240.21 \\
(4,078.70)\end{array}$ & $\begin{array}{c}642.63 \\
(5,817.65) \dagger\end{array}$ & $\begin{array}{c}434.17 \\
(1,881.83)\end{array}$ & $\begin{array}{c}192.15 \\
(1,449.20) \dagger\end{array}$ \\
\hline Median & $2,897.40$ & $1,019.10$ & 0 & 0 & 923.50 & 573 & 430.10 & 110.90 & 68.70 & 0 \\
\hline Percentage increase, $\%^{\mathrm{b}}$ & 121.77 & 82.41 & 248.80 & 165.76 & 33.27 & 46.74 & 32.28 & 41.19 & 34.91 & 31.13 \\
\hline \multicolumn{11}{|c|}{ NAFLD non-progressors $(n=79,245)$} \\
\hline & $\begin{array}{l}\text { With CVD } \\
\mathrm{n}=30,525\end{array}$ & $\begin{array}{c}\text { Without CVD } \\
n=48,720\end{array}$ & $\begin{array}{l}\text { With CVD } \\
n=30,525\end{array}$ & $\begin{array}{l}\text { Without CVD } \\
n=48,720\end{array}$ & $\begin{array}{l}\text { With CVD } \\
\mathrm{n}=30,525\end{array}$ & $\begin{array}{l}\text { Without CVD } \\
\mathrm{n}=48,720\end{array}$ & $\begin{array}{l}\text { With CVD } \\
n=30,525\end{array}$ & $\begin{array}{c}\text { Without CVD } \\
n=48,720\end{array}$ & $\begin{array}{l}\text { With CVD } \\
n=30,525\end{array}$ & $\begin{array}{c}\text { Without CVD } \\
n=48,720\end{array}$ \\
\hline \multicolumn{11}{|l|}{ Pre-index } \\
\hline Mean (SD) & $\begin{array}{c}3,494.71 \\
(6,281.64)\end{array}$ & $\begin{array}{c}1,638.92 \\
(6,601.65)^{\star}\end{array}$ & $\begin{array}{c}1,425.64 \\
(4,215.04)\end{array}$ & $\begin{array}{c}521.05 \\
(2,379.57)^{\star}\end{array}$ & $\begin{array}{c}921.87 \\
(1,522.72)\end{array}$ & $\begin{array}{l}545.77 \\
(669.22)^{\star}\end{array}$ & $\begin{array}{c}845.52 \\
(3,035.81)\end{array}$ & $\begin{array}{c}431.65 \\
(5,635.69)^{\star}\end{array}$ & $\begin{array}{c}301.67 \\
(1,054.81)\end{array}$ & $\begin{array}{c}140.45 \\
(1,359.27)^{\star}\end{array}$ \\
\hline Median & $1,568.10$ & 594.30 & 0 & 0 & 669 & 361.70 & 310.20 & 74.50 & 0 & 0 \\
\hline \multicolumn{11}{|l|}{ Post-index } \\
\hline Mean (SD) & $\begin{array}{c}5,780.34 \\
(11,498.61)\end{array}$ & $\begin{array}{c}2,589.04 \\
(8,295.10) \dagger\end{array}$ & $\begin{array}{c}3,099.99 \\
(9,517.03)\end{array}$ & $\begin{array}{c}1,041.22 \\
(4,550.11) \dagger\end{array}$ & $\begin{array}{c}1,199.12 \\
(1,696.24)\end{array}$ & $\begin{array}{c}774.59 \\
(888.11) \dagger\end{array}$ & $\begin{array}{c}1,091.41 \\
(3,756.37)\end{array}$ & $\begin{array}{c}590.07 \\
(5,901.92) \dagger\end{array}$ & $\begin{array}{c}389.82 \\
(1,829.46)\end{array}$ & $\begin{array}{c}183.16 \\
(1,444.38) \dagger\end{array}$ \\
\hline Median & $2,528.10$ & 962.80 & 0 & 0 & 886.50 & 553.60 & 384.70 & 106.10 & 66.10 & 0 \\
\hline Percentage increase, $\%^{\mathrm{b}}$ & 65.40 & 57.97 & 117.44 & 99.83 & 30.07 & 41.93 & 29.08 & 36.70 & 29.22 & 30.41 \\
\hline \multicolumn{11}{|l|}{$C C(n=411)$} \\
\hline & $\begin{array}{c}\text { With CVD } \\
\mathrm{n}=257\end{array}$ & $\begin{array}{l}\text { Without CVD } \\
n=154\end{array}$ & $\begin{array}{c}\text { With CVD } \\
n=257\end{array}$ & $\begin{array}{l}\text { Without CVD } \\
\quad n=154\end{array}$ & $\begin{array}{l}\text { With CVD } \\
\text { n=257 }\end{array}$ & $\begin{array}{l}\text { Without CVD } \\
\quad n=154\end{array}$ & $\begin{array}{l}\text { With CVD } \\
n=257\end{array}$ & $\begin{array}{l}\text { Without CVD } \\
n=154\end{array}$ & $\begin{array}{c}\text { With CVD } \\
\mathrm{n}=257\end{array}$ & $\begin{array}{c}\text { Without CVD } \\
\quad n=154\end{array}$ \\
\hline \multicolumn{11}{|l|}{ Pre-index } \\
\hline Mean (SD) & $\begin{array}{c}6,307.25 \\
(7,816.98)\end{array}$ & $\begin{array}{c}3,597.31 \\
(6,169.09)^{\star}\end{array}$ & $\begin{array}{c}2,976.16 \\
(5,966.89)\end{array}$ & $\begin{array}{c}1,270.13 \\
(4,099.83)^{\star}\end{array}$ & $\begin{array}{c}1,265.98 \\
(2,157.16)\end{array}$ & $\begin{array}{c}910.89 \\
(739.68)^{*}\end{array}$ & $\begin{array}{l}1,421.15 \\
(2,343.43)\end{array}$ & $\begin{array}{c}1,142.16 \\
(4,230.93)\end{array}$ & $\begin{array}{c}643.96 \\
(1,409.97)\end{array}$ & $\begin{array}{c}274.13 \\
(749.37)^{\star}\end{array}$ \\
\hline Median & $2,946.40$ & $1,546.70$ & 0 & 0 & 911.50 & 712.20 & 633.10 & 255.60 & 112.20 & 0 \\
\hline \multicolumn{11}{|l|}{ Post-index } \\
\hline Mean (SD) & $\begin{array}{c}12,344.84 \\
(15,459.98)\end{array}$ & $\begin{array}{c}6,863.18 \\
(11,208.19) \dagger\end{array}$ & $\begin{array}{c}8,064.47 \\
(12,969.10)\end{array}$ & $\begin{array}{c}3,549.27 \\
(7,673.78) \dagger\end{array}$ & $\begin{array}{c}1,504.02 \\
(2,121.80)\end{array}$ & $\begin{array}{l}1,124.93 \\
(935.65) \dagger\end{array}$ & $\begin{array}{c}2,034.66 \\
(5,004.25)\end{array}$ & $\begin{array}{c}1,865.66 \\
(6,841.63)\end{array}$ & $\begin{array}{c}741.69 \\
(1,586.68)\end{array}$ & $\begin{array}{c}323.32 \\
(983.21) \dagger\end{array}$ \\
\hline Median & 6,996 & $3,085.10$ & $3,374.20$ & 164.60 & $1,185.70$ & 870.10 & 904 & 387.10 & 218.10 & 43.60 \\
\hline Percentage increase, $\%^{\mathrm{b}}$ & 95.72 & 90.79 & 170.97 & 179.44 & 18.80 & 23.50 & 43.17 & 63.35 & 15.18 & 17.94 \\
\hline \multicolumn{11}{|l|}{ DCC $(n=20,614)$} \\
\hline & $\begin{array}{l}\text { With CVD } \\
n=13,943\end{array}$ & $\begin{array}{c}\text { Without CVD } \\
n=6,671\end{array}$ & $\begin{array}{l}\text { With CVD } \\
n=13,943\end{array}$ & $\begin{array}{l}\text { Without CVD } \\
n=6,671\end{array}$ & $\begin{array}{l}\text { With CVD } \\
n=13,943\end{array}$ & $\begin{array}{l}\text { Without CVD } \\
n=6,671\end{array}$ & $\begin{array}{l}\text { With CVD } \\
n=13,943\end{array}$ & $\begin{array}{c}\text { Without CVD } \\
n=6,671\end{array}$ & $\begin{array}{l}\text { With CVD } \\
n=13,943\end{array}$ & $\begin{array}{c}\text { Without CVD } \\
n=6,671\end{array}$ \\
\hline \multicolumn{11}{|l|}{ Pre-index } \\
\hline Mean (SD) & $\begin{array}{c}8,019.22 \\
(13,380.73)\end{array}$ & $\begin{array}{c}3,771.08 \\
(8,991.50)^{\star}\end{array}$ & $\begin{array}{c}4,140.89 \\
(9,539.90)\end{array}$ & $\begin{array}{c}1,461.09 \\
(5,256.91)^{\star}\end{array}$ & $\begin{array}{c}1,394.84 \\
(2,628.94)\end{array}$ & $\begin{array}{c}871.81 \\
(1,247.15)^{\star}\end{array}$ & $\begin{array}{l}1,900.04 \\
(6,335.20)\end{array}$ & $\begin{array}{c}1,173.08 \\
(5,283.65)^{\star}\end{array}$ & $\begin{array}{c}583.44 \\
(1,676.61)\end{array}$ & $\begin{array}{c}265.11 \\
(1,166.30)^{\star}\end{array}$ \\
\hline Median & $3,665.20$ & $1,054.80$ & 0 & 0 & 920.40 & 560.40 & 694.80 & 157.30 & 107.70 & 0 \\
\hline \multicolumn{11}{|l|}{ Post-index } \\
\hline Mean (SD) & $\begin{array}{c}28,789.41 \\
(61,955.20)\end{array}$ & $\begin{array}{c}9,543.87 \\
(28,274.06) \dagger\end{array}$ & $\begin{array}{c}23,612.65 \\
(60,871.07)\end{array}$ & $\begin{array}{c}6,222.68 \\
(25,190.95) \dagger\end{array}$ & $\begin{array}{c}1,787.84 \\
(3,245.22)\end{array}$ & $\begin{array}{c}1,167.97 \\
(1,563.68) \dagger\end{array}$ & $\begin{array}{l}2,425.29 \\
(6,784.48)\end{array}$ & $\begin{array}{c}1,727.42 \\
(6,799.28) \dagger\end{array}$ & $\begin{array}{c}963.63 \\
(2,566.73)\end{array}$ & $\begin{array}{c}425.81 \\
(1,640.06) \dagger\end{array}$ \\
\hline Median & $12,031.50$ & $2,097.90$ & 7,503 & 0 & 1,113 & 790.30 & 888.70 & 198.30 & 198.40 & 0 \\
\hline Percentage increase, $\%^{\mathrm{b}}$ & 259.01 & 153.08 & 470.23 & 325.89 & 28.18 & 33.97 & 27.64 & 47.26 & 65.16 & 60.61 \\
\hline \multicolumn{11}{|l|}{$\mathrm{HCC}(\mathrm{n}=363)$} \\
\hline & $\begin{array}{l}\text { With CVD } \\
n=246\end{array}$ & $\begin{array}{l}\text { Without CVD } \\
\quad n=117\end{array}$ & $\begin{array}{c}\text { With CVD } \\
n=246\end{array}$ & $\begin{array}{l}\text { Without CVD } \\
\quad n=117\end{array}$ & $\begin{array}{l}\text { With CVD } \\
\text { n=246 }\end{array}$ & $\begin{array}{l}\text { Without CVD } \\
\quad n=117\end{array}$ & $\begin{array}{c}\text { With CVD } \\
n=246\end{array}$ & $\begin{array}{l}\text { Without CVD } \\
\quad n=117\end{array}$ & $\begin{array}{l}\text { With CVD } \\
\text { n=246 }\end{array}$ & $\begin{array}{l}\text { Without CVD } \\
\quad n=117\end{array}$ \\
\hline \multicolumn{11}{|l|}{ Pre-index } \\
\hline Mean (SD) & $\begin{array}{c}10,084.45 \\
(19,887.75)\end{array}$ & $\begin{array}{c}9,335.73 \\
(16,851.24)\end{array}$ & $\begin{array}{c}4,889.53 \\
(11,914.82)\end{array}$ & $\begin{array}{c}4,431.41 \\
(10,875.85)\end{array}$ & $\begin{array}{c}1,510.69 \\
(2,340.87)\end{array}$ & $\begin{array}{c}1,275.51 \\
(1,516.05)\end{array}$ & $\begin{array}{c}3,139.84 \\
(10,766.76)\end{array}$ & $\begin{array}{c}3,368.25 \\
(10,353.17)\end{array}$ & $\begin{array}{c}544.38 \\
(1,311.09)\end{array}$ & $\begin{array}{l}260.56 \\
(623.7)^{\star}\end{array}$ \\
\hline Median & $4,328.10$ & $2,493.50$ & $1,030.80$ & 0 & 987.90 & 781.30 & 860.70 & 292 & 93.50 & 0 \\
\hline \multicolumn{11}{|l|}{ Post-index } \\
\hline Mean (SD) & $\begin{array}{c}33,775.26 \\
(33,103.88)\end{array}$ & $\begin{array}{c}40,398.46 \\
(141,627.34)\end{array}$ & $\begin{array}{c}23,484.99 \\
(30,085.32)\end{array}$ & $\begin{array}{c}29,891.02 \\
(141,818.81)\end{array}$ & $\begin{array}{c}2,861.96 \\
(4,075.74)\end{array}$ & $\begin{array}{c}2,219.64 \\
(2,489.18)\end{array}$ & $\begin{array}{c}6,338.71 \\
(12,513.79)\end{array}$ & $\begin{array}{c}7,581.06 \\
(13,390.78)\end{array}$ & $\begin{array}{l}1,089.60 \\
(2,828.6)\end{array}$ & $\begin{array}{c}706.74 \\
(1,438.42)\end{array}$ \\
\hline Median & $27,061.70$ & $21,887.60$ & $17,561.50$ & $10,410.10$ & $1,691.20$ & $1,633.70$ & $1,648.80$ & 841.40 & 358.50 & 125.20 \\
\hline Percentage increase, $\%^{\mathrm{b}}$ & 234.92 & 332.73 & 380.31 & 574.53 & 89.45 & 74.02 & 101.88 & 125.07 & 100.15 & 171.24 \\
\hline
\end{tabular}




\begin{tabular}{|c|c|c|c|c|c|c|c|c|c|c|}
\hline \multirow{3}{*}{ NAFLD $(n=89,698)$} & \multicolumn{10}{|c|}{ Healthcare service component } \\
\hline & \multicolumn{2}{|c|}{ Total costs, $€$} & \multicolumn{2}{|c|}{ Inpatient costs, $€$} & \multicolumn{2}{|c|}{ Outpatient costs, $€$} & \multicolumn{2}{|c|}{ Pharmacy costs, $€$} & \multicolumn{2}{|c|}{ Devices and aids costs, $€$} \\
\hline & $\begin{array}{c}\text { With renal } \\
\text { disease } \\
n=22,108\end{array}$ & $\begin{array}{c}\text { Without renal } \\
\text { disease } \\
n=67,590\end{array}$ & $\begin{array}{c}\text { With renal } \\
\text { disease } \\
n=22,108\end{array}$ & $\begin{array}{c}\text { Without renal } \\
\text { disease } \\
n=67,590\end{array}$ & $\begin{array}{c}\text { With renal } \\
\text { disease } \\
n=22,108\end{array}$ & $\begin{array}{l}\text { Without renal } \\
\text { disease } \\
n=67,590\end{array}$ & $\begin{array}{c}\text { With renal } \\
\text { disease } \\
n=22,108\end{array}$ & $\begin{array}{l}\text { Without renal } \\
\text { disease } \\
n=67,590\end{array}$ & $\begin{array}{c}\text { With renal } \\
\text { disease } \\
n=22,108\end{array}$ & $\begin{array}{c}\text { Without renal } \\
\text { disease } \\
n=67,590\end{array}$ \\
\hline \multicolumn{11}{|l|}{ Pre-index } \\
\hline Mean (SD) & $\begin{array}{c}4,115.74 \\
(7,598.04)\end{array}$ & $\begin{array}{c}2,034.01 \\
(6,322.71)^{*}\end{array}$ & $\begin{array}{c}1,733.39 \\
(5,005.76)\end{array}$ & $\begin{array}{c}704.15 \\
(2,838.43)^{\star}\end{array}$ & $\begin{array}{c}996.31 \\
(1,919.81)\end{array}$ & $\begin{array}{c}630.42 \\
(806.09)^{*}\end{array}$ & $\begin{array}{c}1,045.51 \\
(3,742.27)\end{array}$ & $\begin{array}{c}521.93 \\
(4,973.95)^{*}\end{array}$ & $\begin{array}{c}340.53 \\
(1,072.53)\end{array}$ & $\begin{array}{c}177.51 \\
(1,281.11)^{\star}\end{array}$ \\
\hline Median & $1,726.10$ & 768 & 0 & 0 & 691.70 & 431.70 & 348.90 & 111.30 & 26.60 & 0 \\
\hline \multicolumn{11}{|l|}{ Post-index } \\
\hline Mean (SD) & $\begin{array}{c}9,777.11 \\
(31,240.07)\end{array}$ & $\begin{array}{c}3,766.97 \\
(10,917.26) \dagger\end{array}$ & $\begin{array}{c}6,584.98 \\
(29,902.99)\end{array}$ & $\begin{array}{c}1,917.33 \\
(8,420.17) \dagger\end{array}$ & $\begin{array}{c}1,335.15 \\
(2,165.54)\end{array}$ & $\begin{array}{c}896.9 \\
(1,042.92) \dagger\end{array}$ & $\begin{array}{c}1,400.11 \\
(4,770.53)\end{array}$ & $\begin{array}{c}716.79 \\
(5,310.35) \dagger\end{array}$ & $456.87(1,353.94)$ & $\begin{array}{c}235.94 \\
(1,723.53) \dagger\end{array}$ \\
\hline Median & $3,119.60$ & $1,258.20$ & 0 & 0 & 926.90 & 641.60 & 438.90 & 152 & 69.80 & 0 \\
\hline Percentage increase, $\%^{\mathrm{b}}$ & 137.55 & 85.20 & 279.89 & 172.29 & 34.01 & 42.27 & 33.92 & 37.34 & 34.17 & 32.92 \\
\hline \multicolumn{11}{|c|}{ NAFLD non-progressors $(n=79,245)$} \\
\hline & $\begin{array}{c}\text { With renal } \\
\text { disease } \\
n=18,289\end{array}$ & $\begin{array}{c}\text { Without renal } \\
\text { disease } \\
n=60,956\end{array}$ & $\begin{array}{c}\text { With renal } \\
\text { disease } \\
n=18,289\end{array}$ & $\begin{array}{c}\text { Without renal } \\
\text { disease } \\
n=60,956\end{array}$ & $\begin{array}{c}\text { With renal } \\
\text { disease } \\
n=18,289\end{array}$ & $\begin{array}{l}\text { Without renal } \\
\text { disease } \\
n=60,956\end{array}$ & $\begin{array}{c}\text { With renal } \\
\text { disease } \\
n=18,289\end{array}$ & $\begin{array}{l}\text { Without renal } \\
\text { disease } \\
n=60,956\end{array}$ & $\begin{array}{c}\text { With renal } \\
\text { disease } \\
n=18,289\end{array}$ & $\begin{array}{c}\text { Without renal } \\
\text { disease } \\
n=60,956\end{array}$ \\
\hline \multicolumn{11}{|l|}{ Pre-index } \\
\hline Mean (SD) & $\begin{array}{c}3,760.11 \\
(7,036.27)\end{array}$ & $\begin{array}{c}1,931.81 \\
(6,326.75)^{\star}\end{array}$ & $\begin{array}{c}1,564.75 \\
(4,559.38)\end{array}$ & $\begin{array}{c}660.90 \\
(2,692.40)^{\star}\end{array}$ & $\begin{array}{c}944.45 \\
(1,739.17)\end{array}$ & $\begin{array}{c}614.49 \\
(793.73)^{*}\end{array}$ & $\begin{array}{c}939.48 \\
(3,588.87)\end{array}$ & $\begin{array}{c}486.54 \\
(5,112.88)^{\star}\end{array}$ & $\begin{array}{c}311.43 \\
(1,024.06)\end{array}$ & $\begin{array}{c}169.88 \\
(1,312.49)^{\star}\end{array}$ \\
\hline Median & $1,567.90$ & 738.70 & 0 & 0 & 667.40 & 421 & 311.60 & 105.20 & 0 & 0 \\
\hline \multicolumn{11}{|l|}{ Post-index } \\
\hline Mean (SD) & $\begin{array}{c}6,460.16 \\
(13,734.39)\end{array}$ & $\begin{array}{c}3,025.68 \\
(8,063.77) \dagger\end{array}$ & $\begin{array}{c}3,596.53 \\
(11,580.6)\end{array}$ & $\begin{array}{c}1,305.50 \\
(4,664.83) \dagger\end{array}$ & $\begin{array}{c}1,238.51 \\
(1,947.30)\end{array}$ & $\begin{array}{c}847.99 \\
(976.64) \dagger\end{array}$ & $\begin{array}{c}1,225.46 \\
(4,529.33)\end{array}$ & $\begin{array}{c}650.49 \\
(5,362.13) \dagger\end{array}$ & $\begin{array}{c}399.65 \\
(1,067.4)\end{array}$ & $\begin{array}{c}221.7 \\
(1,734.21) \dagger\end{array}$ \\
\hline Median & $2,659.30$ & $1,165.60$ & 0 & 0 & 888.10 & 617 & 384.40 & 143.40 & 65 & 0 \\
\hline Percentage increase, $\%^{\mathrm{b}}$ & 71.81 & 56.62 & 129.85 & 97.53 & 31.14 & 38 & 30.44 & 33.70 & 28.33 & 30.50 \\
\hline \multicolumn{11}{|l|}{$C C(n=411)$} \\
\hline & $\begin{array}{c}\text { With renal } \\
\text { disease } \\
n=182\end{array}$ & $\begin{array}{l}\text { Without renal } \\
\text { disease } \\
n=229\end{array}$ & $\begin{array}{c}\text { With renal } \\
\text { disease } \\
n=182\end{array}$ & $\begin{array}{l}\text { Without renal } \\
\text { disease } \\
n=229\end{array}$ & $\begin{array}{c}\text { With renal } \\
\text { disease } \\
n=182\end{array}$ & $\begin{array}{l}\text { Without renal } \\
\text { disease } \\
\mathrm{n}=229\end{array}$ & $\begin{array}{c}\text { With renal } \\
\text { disease } \\
n=182\end{array}$ & $\begin{array}{l}\text { Without renal } \\
\text { disease } \\
n=229\end{array}$ & $\begin{array}{c}\text { With renal } \\
\text { disease } \\
n=182\end{array}$ & $\begin{array}{c}\text { Without renal } \\
\text { disease } \\
\mathrm{n}=229\end{array}$ \\
\hline \multicolumn{11}{|l|}{ Pre-index } \\
\hline Mean (SD) & $\begin{array}{c}7,228.60 \\
(8,607.51)\end{array}$ & $\begin{array}{c}3,752.59 \\
(5,749.72)^{*}\end{array}$ & $\begin{array}{c}3,570.08 \\
(6,593.45)\end{array}$ & $\begin{array}{c}1,356.86 \\
(3,974.22)^{\star}\end{array}$ & $\begin{array}{c}1,353.58 \\
(2,467.17)\end{array}$ & $\begin{array}{c}957.56 \\
(862.14)^{*}\end{array}$ & $\begin{array}{c}1,563.61 \\
(2,656.36)\end{array}$ & $\begin{array}{c}1,120.30 \\
(3,538.68)\end{array}$ & $\begin{array}{c}741.33 \\
(1,560.35)\end{array}$ & $\begin{array}{c}317.87 \\
(808.82)^{*}\end{array}$ \\
\hline Median & $3,560.10$ & $1,651.70$ & 0 & 0 & 977.30 & 722.20 & 690.70 & 342.40 & 215.50 & 0 \\
\hline \multicolumn{11}{|l|}{ Post-index } \\
\hline Mean (SD) & $\begin{array}{c}14,145.75 \\
(17,697.43)\end{array}$ & $\begin{array}{c}7,227.19 \\
(9,768.77) \dagger\end{array}$ & $\begin{array}{c}9,505.64 \\
(14,981.93)\end{array}$ & $\begin{array}{l}3,882.66 \\
(6,688) \dagger\end{array}$ & $\begin{array}{c}1,621.31 \\
(2,438.26)\end{array}$ & $\begin{array}{l}1,155.87 \\
(941.89) \dagger\end{array}$ & $\begin{array}{c}2,208.73 \\
(5,964.12)\end{array}$ & $\begin{array}{c}1,782.67 \\
(5,587.63)\end{array}$ & $\begin{array}{c}810.06 \\
(1,769.66)\end{array}$ & $\begin{array}{c}\text { 406, } \\
(995.31) \dagger\end{array}$ \\
\hline Median & $7,924.10$ & $3,710.10$ & $4,007.20$ & 400.70 & $1,258.20$ & 912.80 & 862.80 & 552.60 & 232.30 & 65.90 \\
\hline Percentage increase, $\%^{\mathrm{b}}$ & 95.69 & 92.59 & 166.26 & 186.15 & 19.78 & 20.71 & 41.26 & 59.12 & 9.27 & 27.72 \\
\hline \multicolumn{11}{|l|}{$\operatorname{DCC}(n=20,614)$} \\
\hline & $\begin{array}{l}\text { With renal } \\
\text { disease } \\
n=9,977\end{array}$ & $\begin{array}{c}\text { Without renal } \\
\text { disease } \\
n=10,637\end{array}$ & $\begin{array}{c}\text { With renal } \\
\text { disease } \\
\mathrm{n}=9,977\end{array}$ & $\begin{array}{c}\text { Without renal } \\
\text { disease } \\
n=10,637\end{array}$ & $\begin{array}{c}\text { With renal } \\
\text { disease } \\
\mathrm{n}=9,977\end{array}$ & $\begin{array}{l}\text { Without renal } \\
\text { disease } \\
n=10,637\end{array}$ & $\begin{array}{c}\text { With renal } \\
\text { disease } \\
n=9,977\end{array}$ & $\begin{array}{l}\text { Without renal } \\
\quad \text { disease } \\
n=10,637\end{array}$ & $\begin{array}{l}\text { With renal } \\
\text { disease } \\
\mathrm{n}=9,977\end{array}$ & $\begin{array}{c}\text { Without renal } \\
\text { disease } \\
n=10,637\end{array}$ \\
\hline \multicolumn{11}{|l|}{ Pre-index } \\
\hline Mean (SD) & $\begin{array}{c}9,142.51 \\
(15,043.26)\end{array}$ & $\begin{array}{c}4,301.40 \\
(8,333.76)^{\star}\end{array}$ & $\begin{array}{c}4,824.66 \\
(10,768.88)\end{array}$ & $\begin{array}{c}1,818.91 \\
(5,150.71)^{\star}\end{array}$ & $\begin{array}{c}1,511.36 \\
(3,057.48)\end{array}$ & $\begin{array}{c}957.52 \\
(1,111.09)^{\star}\end{array}$ & $\begin{array}{c}2,159.22 \\
(7,160.27)\end{array}$ & $\begin{array}{c}1,201.03 \\
(4,669.98)^{\star}\end{array}$ & $\begin{array}{c}647.27 \\
(1,848.21)\end{array}$ & $\begin{array}{c}323.94 \\
(1,151.66)^{\star}\end{array}$ \\
\hline Median & $4,256.30$ & $1,512.20$ & 400 & 0 & 951.70 & 674.20 & 795.60 & 257.80 & 125.80 & 0 \\
\hline \multicolumn{11}{|l|}{ Post-index } \\
\hline Mean (SD) & $\begin{array}{c}34,209.56 \\
(70,285.98)\end{array}$ & $\begin{array}{c}11,635.72 \\
(28,456.91) \dagger\end{array}$ & $\begin{array}{c}28,496.53 \\
(69,175.87)\end{array}$ & $\begin{array}{c}8,125.67 \\
(26,344.62) \dagger\end{array}$ & $\begin{array}{c}1,933.96 \\
(3,705.38)\end{array}$ & $\begin{array}{c}1,262.02 \\
(1,550.79) \dagger\end{array}$ & $\begin{array}{c}2,715.91 \\
(7,673.48)\end{array}$ & $\begin{array}{c}1,715.04 \\
(5,815.62) \dagger\end{array}$ & $\begin{array}{c}1,063.15 \\
(2,753.85)\end{array}$ & $\begin{array}{c}532.98 \\
(1,787.80) \dagger\end{array}$ \\
\hline Median & $15,542.30$ & $3,230.50$ & $10,471.60$ & 771.10 & $1,130.20$ & 900.20 & 998.70 & 333.30 & 237.70 & 70.90 \\
\hline Percentage increase, $\%^{\mathrm{b}}$ & 274.18 & 170.51 & 490.64 & 346.73 & 27.96 & 31.80 & 25.78 & 42.80 & 64.25 & 64.53 \\
\hline \multicolumn{11}{|l|}{$\operatorname{HCC}(n=363)$} \\
\hline & $\begin{array}{c}\text { With renal } \\
\text { disease } \\
n=197\end{array}$ & $\begin{array}{l}\text { Without renal } \\
\text { disease } \\
n=166\end{array}$ & $\begin{array}{c}\text { With renal } \\
\text { disease } \\
n=197\end{array}$ & $\begin{array}{l}\text { Without renal } \\
\text { disease } \\
n=166\end{array}$ & $\begin{array}{c}\text { With renal } \\
\text { disease } \\
n=197\end{array}$ & $\begin{array}{l}\text { Without renal } \\
\text { disease } \\
n=166\end{array}$ & $\begin{array}{c}\text { With renal } \\
\text { disease } \\
n=197\end{array}$ & $\begin{array}{l}\text { Without renal } \\
\text { disease } \\
n=166\end{array}$ & $\begin{array}{c}\text { With renal } \\
\text { disease } \\
n=197\end{array}$ & $\begin{array}{l}\text { Without renal } \\
\text { disease } \\
n=166\end{array}$ \\
\hline \multicolumn{11}{|l|}{ Pre-index } \\
\hline Mean (SD) & $\begin{array}{c}11,677.31 \\
(22,027.04)\end{array}$ & $\begin{array}{c}7,666.40 \\
(14,214.96)^{\star}\end{array}$ & $\begin{array}{c}5,972.73 \\
(13,937.79)\end{array}$ & $\begin{array}{c}3,281.16 \\
(7,703.01)^{*}\end{array}$ & $\begin{array}{l}1,597.22 \\
(2,611.2)\end{array}$ & $\begin{array}{c}1,242.25 \\
(1,269.16)\end{array}$ & $\begin{array}{c}3,507 \\
(10,463.75)\end{array}$ & $\begin{array}{c}2,865.11 \\
(10,827.01)\end{array}$ & $\begin{array}{c}600.37 \\
(1,449.12)\end{array}$ & $\begin{array}{c}277.89 \\
(559.73)^{\star}\end{array}$ \\
\hline Median & $4,631.60$ & $2,938.40$ & $1,060.20$ & 0 & 992.80 & 845.30 & 871.20 & 420 & 97.10 & 0.30 \\
\hline \multicolumn{11}{|l|}{ Post-index } \\
\hline Mean (SD) & $\begin{array}{c}45,736.74 \\
(112,231.75)\end{array}$ & $\begin{array}{c}24,248.17 \\
(23,136.01) \dagger\end{array}$ & $\begin{array}{c}34,408.32 \\
(112,032.48)\end{array}$ & $\begin{array}{c}15,036.85 \\
(19,727.30) \dagger\end{array}$ & $\begin{array}{c}3,060.83 \\
(4,490.14)\end{array}$ & $\begin{array}{c}2,173.22 \\
(2,200.14) \dagger\end{array}$ & $\begin{array}{c}7,114.07 \\
(13,030.41)\end{array}$ & $\begin{array}{c}6,294.19 \\
(12,540.54)\end{array}$ & $\begin{array}{c}1,153.52 \\
(3,088.41)\end{array}$ & $\begin{array}{c}743.90 \\
(1,408.30)\end{array}$ \\
\hline Median & $28,895.20$ & $19,051.20$ & $19,438.80$ & 9,017 & $1,794.90$ & $1,440.30$ & 1,866 & 960.60 & 360.10 & 142 \\
\hline Percentage increase, $\%^{\mathrm{b}}$ & 291.67 & 216.29 & 476.09 & 358.28 & 91.64 & 74.94 & 102.85 & 119.68 & 92.13 & 167.69 \\
\hline
\end{tabular}

${ }^{2}$ Results for patients with LT are not reported owing to small sample size. ${ }^{\text {P}}$ Percentage increase from the pre-index to the post-index period. ${ }^{*} \mathrm{p}<0.05$ for pre-index with renal disease $v s$. without renal disease. $\nmid p<0.05$ for post-index with renal disease vs. without renal disease. CC: compensated cirrhosis; DCC: decompensated cirrhosis; HCC: hepatocellular carcinoma; LT: liver transplantation; NAFLD: nonalcoholic fatty liver disease; SD: standard deviation. 